Volume 13

\title{
The Mass Murder of the European Jews and the Concept of 'Genocide' in the Nuremberg Trials: Reassessing Raphaël Lemkin's Impact
}

\author{
Alexa Stiller \\ University of Bern, Switzerland
}

Follow this and additional works at: https://digitalcommons.usf.edu/gsp

\section{Recommended Citation}

Stiller, Alexa (2019) "The Mass Murder of the European Jews and the Concept of 'Genocide' in the Nuremberg Trials: Reassessing Raphaël Lemkin's Impact," Genocide Studies and Prevention: An International Journal: Vol. 13: Iss. 1: 144-172.

DOI:

https://doi.org/10.5038/1911-9933.13.1.1610

Available at: https://digitalcommons.usf.edu/gsp/vol13/iss1/14

This Articles is brought to you for free and open access by the Open Access Journals at Digital Commons @ University of South Florida. It has been accepted for inclusion in Genocide Studies and Prevention: An International Journal by an authorized editor of Digital Commons @ University of South Florida. For more information, please contact digitalcommons@usf.edu. 


\title{
The Mass Murder of the European Jews and the Concept of 'Genocide' in the Nuremberg Trials: Reassessing Raphaël Lemkin's Impact
}

\author{
Alexa Stiller \\ University of Bern, Columbia University (Visiting Scholar) \\ Bern, Switzerland
}

Raphaël Lemkin invented the concept of genocide. The term was prominently used in the indictment before the International Military Tribunal (IMT). In the course of the Nuremberg trial, all four prosecution authorities employed Lemkin. In the twelve subsequent trials before the purely USAmerican Nuremberg Military Tribunals (NMT), the prosecution further defined and differentiated 'genocide.' In these tribunals, the term even made its way into a verdict. In all thirteen Nuremberg trials, the lawyers involved brought the persecution and extermination of European Jews to trialsometimes explicitly the mass murder, sometimes persecution and exploitation measures, which resulted nevertheless in exclusion, expulsion, and death. Lemkin's study of Nazi occupation policy became an essential reading for Nuremberg lawyers. He also corresponded with members of the American and British prosecution authorities during the IMT and NMT trials. But what impact did he have on the Nuremberg Trials?

Building on the research of recent years, my working hypothesis is that Lemkin had virtually no influence on the course of these processes-although the concept of 'genocide' did. The original concept was very broad and open to various interpretations, however, over the years of the Nuremberg proceedings the concept was narrowed down to the crime of direct and planned mass murder. ${ }^{1}$ A final definition of genocide was only given with the drafting of the Genocide Convention, which standardized the term (even though there are still problematic ambiguities, but this is another issue that is not to be dealt with here). What has not been sufficiently emphasized in research to date is the question of the interdependence of the concept of 'genocide' and the mass murder of the European Jews or the 'Holocaust' between 1944 and 1948. The assumption underlying this essay is that the extermination of Europe's Jews and 'genocide' were not used congruently in the Nuremberg trials. To illustrate this, I will deal here with both the question of how the persecution and murder of the Jews was interpreted in the Nuremberg trials and how the concept of 'genocide' was used. At the same time, I will mention a few other persons next to Lemkin who influenced the historical interpretations of the past and the legal concepts in early postwar period. The aim of the paper is to unravel the nexus of the 'Holocaust' and 'genocide' during the years 1945 to 1948, i.e. in a pre-Genocide-Convention time (as an established norm) and a presingularity-of-the-Holocaust thesis time (as a narrative of memory politics). ${ }^{2}$

The historicization of the criminal prosecution for the persecution and mass murder of the Jews in the Nuremberg trials, on the one hand, and the historicization of the application of the concept of 'genocide,' on the other, is valuable for several reasons. First, the singularity of the Holocaust was controversially discussed in Holocaust and Genocide Studies for many years (without having led to an agreement), ${ }^{3}$ secondly, the use of the term 'genocide' in the Genocide Studies itself is increasingly being critically questioned; thirdly, the fields of Holocaust research, the comparative research on mass violence, and the research on Nazi Germany and its occupation policy are increasingly separating themselves from each other. Whereas anti-Semitism was related to Nazi racial theory and ideology and the anti-Jewish practice was a part of the whole policy of mass violence of the Nazi regime before and after 1939. There is the question of whether the mass murder of the Jews can thoroughly be investigated without the context of occupation policy, hunger policy, the exploitation of prisoners in the concentration camps, the murders of the

\footnotetext{
${ }^{1}$ Alexa Stiller, "Semantics of Extermination. The Use of the New Term of Genocide in the Nuremberg Trials and the Genesis of a Master Narrative," in Reassessing the Nuremberg Military Tribunals. Transitional Justice, Trial Narratives, and Historiography, eds. Kim C. Priemel and Alexa Stiller (New York: Berghahn, 2012), 104-133.

${ }^{2}$ For the scholarly debate about the uniqueness of the Holocaust and a plea for contextualization see for example: Sybil Milton, "The Context of the Holocaust," German Studies Review 13 (1990), 269-283; Henry Friedlander, The Origins of Nazi Genocide: From Euthanasia to the Final Solution (Chapel Hill: University of North Carolina Press, 1995).

${ }^{3}$ However, the criticism of the thesis of the singularity of the Holocaust in research does not mean that peculiarities are not seen in comparison with other mass murders or persecution policies.
} 
mentally-ill patients, the Sinti and Roma, the Soviet prisoners of war, and so on. Was the Holocaust part of a more comprehensive extermination policy of the Nazi regime or an independent, separate program? These contextualization questions, which arise for research on the Nazi regime (and thus also for German history as a whole, but also for other national historiographies), have been less relevant for genocide research because of their methodological approach of comparing different mass violence phenomena. For comparative research, especially from a social science angle, other questions arose which aim to identify or typologize commonalities and differences before, during, and after the process of mass violence-and such a perspective is thus inevitably to a certain extent de-contextualized. Hence, scholars have been arguing about the question whether the Holocaust is comparable for decades with no end in sight. Obviously, this is because this is not only a question about historical events: Holocaust and genocide have long since become concepts of national selfassurance and political instrumentalization. ${ }^{4}$

This article deals with the first act of the history of the current discussion about the two terms Holocaust and genocide. It examines how the prosecutors and judges of the Nuremberg trials related the murder of the European Jews to Raphaël Lemkin's concept of genocide. Nuremberg is seen and analyzed here as the earliest transnational social (and in this case also public) space for the negotiation of terms, concepts, interpretations, and narratives in international criminal law, moral and historical politics after the Second World War. I will begin with a brief explanation of the history of the terms, before first going into details of the trial before the International Military Tribunal (1945-1946) and then into the trials before the Nuremberg Military Tribunals (1946-1949). Conclusively, I will assess Lemkin's influence on Nuremberg's narratives of mass murder and violence.

\section{A Short History of the Concepts}

The Greek term 'holókaustos' literally means 'completely burned' and was used in the Greek Bible translation for animals sacrificed by fire on the altar. After a change in meaning in the Middle Ages, which associated the term with the burning of people-whether in the course of pogroms against Jews or the executions of alleged witches at the stake-it was established between the end of the 19th century and the 1940s for describing a large number of victims of natural disasters, of massacres, and mass murders. ${ }^{5}$ The term was first comprehensively used for the extermination of a particular group in the case of the Armenians. In September 1895, the New York Times described several consecutive mass murders of Armenians as a "Holocaust." A few years later an English book with the title The Young Turks and the Truth about the Holocaust in Asia Minor during April 1909 was published. In 1923, it was Winston Churchill who used the term for the mass murder of Armenians during the First World War. ${ }^{6}$

The term first appeared at the end of 1942 in connection with the murder of Polish Jews by the Nazis: A London newspaper described the mass murder as "Holocaust." As a synonym for the extermination of the European Jews, the term only became established in everyday American language in the course of the Eichmann Trial. ${ }^{7}$ In Germany, the term became more common with the US television film of the same title from 1978 and gradually replaced Auschwitz as a synonym for the Nazi extermination policy from the mid-1990s onwards. ${ }^{8}$ Whether the term only included

\footnotetext{
${ }^{4}$ On the criticism of the concept of genocide, see e.g. Christian Gerlach, "Extremely Violent Societies: An Alternative to the Concept of Genocide," Journal of Genocide Research 8, no. 4 (2006), 455-471; Christian Gerlach, Extremely Violent Societies: Mass Violence in the Twentieth-Century World (Cambridge, UK: Cambridge University Press, 2010); Jacques Sémelin, Purify and Destroy: The Political Uses of Massacre and Genocide (London: Hurst, 2013).

${ }^{5}$ Anja Kurths, Shoahgedenken im israelischen Alltag: Der Umgang mit der Shoah in Israel seit 1948 am Beispiel der Gedenkstätten Beit Lohamei HaGetaot, Yad Vashem und Beit Terezin (Berlin: Frank \& Timme, 2008), 17.

${ }^{6}$ Hans-Lukas Kieser, “Die Armenierverfolgungen in der spätosmanischen Türkei. Neue Quellen und Literatur zu einem unbewältigten Thema," Schweizerischen Zeitschrift für Geschichte/Revue Suisse d'histoire 51, no. 1 (2001), 97-105, here fn. 1 .

${ }^{7}$ Jon Petrie, "The Secular Word HOLOCAUST. Scholarly Myths, History, and 20th Century Meanings," Journal of Genocide Research 2, no. 1 (2000), 31-63.

${ }^{8}$ Detlev Claussen, "Veränderte Vergangenheit. Über das Verschwinden von Auschwitz," in Shoah. Formen der Erinnerung. Geschichte, Philosophie, Literatur, Kunst, eds. Nicolas Berg, et al (Munich: Fink, 1996), 77-92. See also Jeffrey Shandler, While America Watches: Televising the Holocaust (Oxford: Oxford University Press, 1999), 137.
} 
the Nazi persecution and extermination of Jews or also the murder of the mentally ill, of the Sinti \& Roma and other persecution measures and mass murders, however, remained open in German research. Regarding the Nuremberg Trials, Holocaust is therefore not a historical-contemporary term. Instead, the terms extermination, destruction, and annihilation were used throughout the thirteen Nuremberg trials to describe the mass murder of the Jews.

The term genocide, on the other hand, is a term used at the time. Genocide was employed by the Nuremberg prosecutors. In the German edition of the minutes of the trial before the IMT the word was mostly translated as Völkermord but also simply as mass murder. The term was created by Polish-Jewish lawyer Raphaël Lemkin for a conceptual and juridical redefinition of mass crimes against civilians by the Nazis in the occupied territories. However, the term already existed in other languages: in French nationicides ${ }^{9}$ and in German Völkermord. The latter German term originated from the time after the suppression of the national Polish November Uprising of 1830/31 by the Russian Empire. The German bourgeois-liberal movement expressed solidarity with the Polish insurgents who mostly went into exile in France via the German lands (as a sign of this solidarity, the German republican Black-Red-Golden flag and the Polish national flag were hoisted at the Hambach Festival in 1832). In the course of the glorification of the Polish uprising by the German national movement, more than 1,000 so-called Polish songs were written in which the oppression of the Polish nation by the Russian Empire was described as Völkermord. ${ }^{10}$ In other words, the term was originally a political word that denounced a repressive policy of assimilation and foreign rule. It was subsequently widely used in Germany, although it can be assumed that there were various shifts in meaning. Since 1914, war opponents in particular used the word to describe the First World War. ${ }^{11}$ Whether Lemkin knew the German term Völkermord, his connotations or the historical context in which it originated, is not known. What is interesting, however, is that in his study Axis Rule in Occupied Europe Lemkin used the term partly in the original, more ethnonational meaning. The political, socio-economic and cultural extermination of a nation or group, however, coupled Lemkin in his definition of genocide with the actual biological and physical extermination of a nation or group. Lemkin's original definition from 1944 was:

Generally speaking, genocide does not necessarily mean the immediate destruction of a nation, except when accomplished by mass killings of all members of a nation. It is rather to signify a coordinated plan of different actions aiming at the destruction of essential foundations of the life of national groups, with the aim of annihilating the groups themselves. The objectives of such a plan would be disintegration of the political and social institutions, of culture, language, national feelings, religion, and the economic existence of national groups, and the destruction of the personal security, liberty, health, dignity, and even the lives of the individuals belonging to such groups. Genocide is directed against the national group as an entity, and the actions involved are directed against individuals, not in their individual capacity, but as members of the national group. ${ }^{12}$

\footnotetext{
${ }^{9}$ Douglas Irvin-Erickson, Raphaël Lemkin and the Concept of Genocide (Philadelphia: University of Pennsylvania Press, 2017), 83. See for a contemporary translation of the word into German, Chrétien Frédéric Schwan, Nouveau Dictionnaire françois-allemand: Extrait de son grand Dictionnaire par lui même, Tome II, nouv. éd., rev., corr. et augm. (Tübingen: Cotta, 1807), 371.

${ }^{10}$ The first mention of the German word Völkermord, as far as known, was made by August Graf von Platen in a poem or Volkslied resp. Polenlied (Polish Song) from 1831. Kurt Böttcher et al., eds., Geflügelte Worte: Zitate, Sentenzen und Begriffe in ihrem geschichtlichen Zusammenhang (Leipzig: VEB Bibliographisches Institut, 1981), 466. On the Polenlieder see Gabriela Brudzyńska-Němec, "Polenbegeisterung in Deutschland nach 1830," in Europäische Geschichte Online, ed. The Institut für Europäische Geschichte (Mainz, 2010), accessed August 31, 2018, http://ieg-ego.eu/de/ threads/europaeische-medien/europaeische-medienereignisse/1830er-revolution/gabriela-brudzynska-nemecpolenbegeisterung-in-deutschland-nach-1830.

${ }^{11}$ The history of the German term Völkermord cannot be further illustrated here. A short quantitative search in the digital library project Gutenberg-DE (consisting of classical German literature) has already resulted in 59 entries. Among others, the following persons used the term in their writings: Moritz Graf von Strachwitz (1850), Gustav Freytag (1864), Heinrich von Treitschke (1879), Bertha von Suttner (1889), Clara Zetkin (1914), Rosa Luxemburg (1914), Erich Mühsam (1914), Sigmund Freud (1915), Carl von Ossietzky (1920), Theodor Lessing (1925), and Joachim Ringelnatz (1928), search results accessed October 9, 2018, http://gutenberg.spiegel.de/suche?q=v\%F6lkermord.
} 
In Axis Rule, Lemkin terminologically and conceptually tried to grasp the new character of Nazi occupation policy and the committed crimes. He proposed the new term genocide to replace the older terms denationalization or specifically Germanization, etc., i.e. forced assimilations which had constituted a large part of the debate on international law in the interwar period, precisely because of the legislation on protecting minorities in Europe set by the League of Nations. ${ }^{13} \mathrm{He}$ also recommended the new term because he realized that the Nazi regime's occupation policy contained a new dimension of extermination. Clearly, he was not interested in synthesizing a historical-analytical concept, but in the creation of a new element of offense under international criminal law. On the one hand, it is not surprising that the prosecutors in the Nuremberg trials, in the absence of other adequate terminology for the Nazi extermination policy and in the course of emphasizing the novel character of Nazi crimes, rapidly took up the term 'genocide;' on the other hand, due to its broad definition and the combination of very different criminal offenses, the concept also caused them difficulties.

It is true that the definitional difficulties were decimated (albeit not eliminated) by The Convention on the Prevention and Punishment of Genocide adopted by the United Nation's General Assembly in December 1948. However, the codified text of the Genocide Convention stressed the intended mass murder as an essential feature-and as just shown, Lemkin's original concept had not done so. The UN Convention defined in Article II:

[G]enocide means any of the following acts committed with intent to destroy, in whole or in part, a national, ethnical, racial, or religious group, as such: (a) Killing members of the group; (b) Causing serious bodily or mental harm to members of the group; (c) Deliberately inflicting on the group conditions of life calculated to bring about its physical destruction in whole or in part; (d) Imposing measures intended to prevent births within the group; (e) Forcibly transferring children of the group to another group. ${ }^{14}$

The narrowing of the definition to physical or biological mass violence was due to legal pragmatism - after all, a law must be applicable — but also to political interests of the members of the United Nations at that time..$^{15}$ Nonetheless, despite the reduction of the Convention to mass murder, some of Lemkin's original concept has been remained, as evidenced by the criminalization of involuntary adoptions and forced assimilation of children of one group by another group. But this narrowing of the term also seems to reflect Lemkin's own development in the post-war years,

${ }^{12}$ Raphaël Lemkin, Axis Rule in Occupied Europe. Laws of Occupation, Analysis of Government, Proposals for Redress (Washington, DC: Carnegie Endowment for International Peace, 1944), 79.

${ }^{13}$ In the years 1919 to 1939, however, Germanization was less in debate than Italianization, Polonization, etc. See Mark Mazower, Dark Continent: Europe's Twentieth Century (London: Allen Lane, 1998), 41-75; Martin Scheuermann, Minderheitenschutz contra Konfliktverhütung? Die Minderheitenpolitik des Völkerbundes in den zwanziger Jahren (Marburg: Verlag Herder-Institut, 2000); Carole Fink, Defending the Rights of Others: The Great Powers, the Jews, and International Minority Protection, 1878-1938 (Cambridge, UK: Cambridge University Press, 2004). Like Lemkin, Josef L. Kunz, an Austrian-American legal scholar and expert in the field of minority rights, put the Nazi persecution and extermination policy in the context of minority politics. See Josef L. Kunz, "The Future of the International Law for the Protection of National Minorities," The American Journal of International Law 39 (1945), 89-95. On the discussion of international law in the interwar period see Daniel Marc Segesser, Recht statt Rache oder Rache durch Recht? Die Ahndung von Kriegsverbrechen in der internationalen fachwissenschaftlichen Debatte 1872-1945 (Paderborn: Schöningh, 2010); Claudia Kraft, "Völkermord als delictum iuris gentium - Raphaël Lemkins Vorarbeiten für eine Genozidkonvention," Jahrbuch des Simon-Dubnow-Instituts 4 (2005), 79-98; Irvin-Erickson, Raphaël Lemkin, 26.

${ }^{14}$ United Nations, General Assembly Resolution 260, Convention on the Prevention and Punishment of the Crime of Genocide, December 9, 1948 (UN Doc. A/RES/260(III)).

${ }^{15}$ See Josef L. Kunz, “The United Nations Convention on Genocide," The American Journal of International Law 43 (1949), 738-746; Johannes Morsink, "Cultural Genocide, the Universal Declaration, and Minority Rights," Human Rights Quarterly 21 (1999), 1009-1060; William A. Schabas, Genocide in International Law: The Crimes of Crime (Cambridge, UK: Cambridge University Press, 2000); Matthew Lippman, "A Road Map to the 1948 Convention on the Prevention and Punishment of Genocide," Journal of Genocide Research 4 (2002), 177-195; Jost Dülffer, "The United Nations and the Origins of the Genocide Convention 1946-1948," in The Genocide Convention Sixty Years after its Adoption, eds. Christoph Safferling and Eckart Conze (The Hague: Asser Press, 2010), 55-68; Stiller, Semantics of Extermination; Irvin-Erickson, Raphäl Lemkin, 152-196; Anton Weiss-Wendt, The Soviet Union and the Gutting of the UN Genocide Convention (Madison: University of Wisconsin Press, 2017), 64-96. 
for he took an active part in the definition of genocide within the UN. At the same time, a similar development occurred in the course of the Nuremberg Trials.

\section{Genocide and the Holocaust in the International Military Tribunal Indictment}

Charges were first brought against twenty-four defendants and six organizations on 6 October 1945. The Charter of the International Military Tribunal (IMT) formed the legal basis of this international criminal tribunal. It defined the offenses for which this temporary court was responsible: crimes against peace, war crimes, and crimes against humanity. The new category of crimes against humanity included "murder, extermination, enslavement, deportation, and other inhuman acts" and "persecutions on political, racial, or religious grounds" not only during the war but also before. However, it was only justiciable in connection with one of the other two offenses crimes against peace or war crimes. ${ }^{16}$ The conspiracy or common plan was later included as a fourth charge. The idea of making the policies of the Nazi regime criminally prosecutable by means of the legal construct of the conspiracy (and on the second level by means of organizational crime) emerged from the advocacy of US jurists-although the Soviet negotiating partner had proposed something similar, named complicity ${ }^{17}$ Linked to the war of aggression, the legal construct of conspiracy was particularly intended to solve the legal-dogmatic problems of sovereignty and the indirectness of individuals under international law. ${ }^{18}$

In the indictment, drawn up jointly by the four Allied prosecuting authorities, the persecution and extermination of the Jews were also listed under three of the four offenses. Firstly, under the charge of conspiracy and the common plan; anti-Semitism and Nazi race ideology were viewed as a means of incitement. ${ }^{19}$ Secondly, on the charge of war crimes, committed in general in the context of the execution of a wider program, called "genocide... particularly [against] Jews, Poles, Gypsies and others." ${ }^{20}$ However, the following list of mass murders in ghettos, concentration camps, and the places of mass executions in Eastern Europe mostly named Soviet citizens as victims; only in two cases Jewish victims were explicitly mentioned: concerning the ghetto of Lemberg [Lviv] and the massacre in Kamenetz-Podolsk [Kamianets-Podilskyi]. ${ }^{21}$ Thirdly, the persecution and extermination of the Jews was explicitly treated under the charge of crimes against humanity. Here, the tribunal charged the persecution of the Jewish Germans before the war and mass executions of Jews during the war from Latvia to the North Caucasus as well as the murder of 70,000 Jews in Yugoslavia..$^{22}$

The indictments reveal two different interpretations of the murder of the Jews. On the one hand, an emphasis of the crimes as a form of 'genocide:' "They [the defendants] conducted deliberate and systematic genocide, viz., the extermination of racial and national groups, against the civilian populations of certain occupied territories in order to destroy particular races and classes of people and national, racial, or religious groups, particularly Jews, Poles, and Gypsies and others." ${ }^{23}$ Put differently, Jewish victims were named among other groups of victims, all of whom were seen as equally affected by the extermination policy. On the other hand, the US prosecution sought to punish the persecution of the Jewish Germans before 1939 and interpreted the individual

\footnotetext{
16 "Charter of the International Military Tribunal," in Trial of the Major War Criminals before the International Military Tribunal, (hereafter IMT), Volumes 1-42, November 14, 1945- October 1, 1946 (Nuremberg: 1947-1949), vol. I, 11.

${ }^{17}$ Hirsch has highlighted this common ground between US and SU lawyers in legal policy thinking. See Francine Hirsch, "The Soviets at Nuremberg: International Law, Propaganda, and the Making of the Postwar Order," American Historical Review 113, no. 3 (2008), 701-730.

${ }^{18}$ Kim C. Priemel and Alexa Stiller, "Wo 'Nürnberg' liegt. Zur historischen Verortung der Nuernberg Military Tribunals," in NMT. Die Nürnberger Militärtribunale zwischen Geschichte, Gerechtigkeit und Rechtschöpfung, eds. Kim C. Priemel and Alexa Stiller (Hamburg: Hamburger Edition, 2013), 9-63, here 19, 31- 32.

${ }^{19}$ Indictment, 6 Oct 1945, IMT, I, 33.

${ }^{20}$ Ibid., $43-44$.

${ }^{21} \mathrm{Ibid} ., 47-49$. Place names are specified in the text in the same way as in the English IMT protocol.

${ }^{22}$ Ibid., 67. Mentioned were mass executions of Jews in Kislovodsk (near Riga), Lutsk, Sarny, Kiev and Dniepropetovsk [Dnipro].

${ }^{23}$ Ibid., 43-44.
} 
steps of the persecution of the Jewish Germans up to the extermination of the European Jews as a coherent, self-contained process. According to the corresponding section of the indictment, the extermination of Europe's Jews had been planned by the accused together (the common plan) and for a long time (the conspiracy). ${ }^{24}$

Lemkin played an active role in including the term genocide in the indictment. On May 4, 1945, two days after Justice Robert H. Jackson's appointment to the US Chief of Counsel, Lemkin wrote to Jackson and sent him a published article on his genocide concept. In addition, the Washington Post had prominently staged the new term genocide in two editorials in November 1944 and May 1945. Jackson read both Lemkin's article and the book. From then on, the concept was widely discussed within the American delegation at the conference in London where the four allied powers negotiated the conditions of the International Military Tribunal. Jackson, however, did not invite Lemkin to join his team. Lemkin remained employed in the War Department, but was given the opportunity to join the Judge Advocate General (JAG). Through the JAG and an invitation from Murray C. Bernays, a co-worker of Jackson, Lemkin nevertheless came to London. ${ }^{25}$ Ten days after the London Agreement (including the Charter of the IMT) was signed, Lemkin submitted a proposal to the US prosecution to charge the prominent German geographer Karl Haushofer in the Nuremberg trial. He saw Haushofer's geopolitical ideas as a link between the war of aggression and the Nazis' conquest of 'living space,' which in his view was central to the following mass violence or 'genocide.' ${ }^{26}$ In September 1945, Lemkin proposed to Telford Taylor, another member of Jackson's team, that prosecutors should use his genocide concept. ${ }^{27}$ Another US staff member, Sidney S. Alderman, also recalled that Lemkin visited him frequently at his London office to ensure that the word 'genocide' was included in the indictment. ${ }^{28}$ Although personal cooperation with Lemkin was apparently unwelcomed, ${ }^{29}$ the new word found its way into the indictment and the American lawyers also recommended Axis Rule to the other delegations. ${ }^{30}$

\section{Opening Statements and Argumentation of the Four Prosecution Teams}

For practical reasons the four prosecution teams split up the responsibility of litigating the four charges. This meant that each prosecution did not address all of the crimes. ${ }^{31}$ The US prosecution, the Office of Chief of Counsel for the Prosecution of Axis Criminality (OCCPAC) under Jackson, presented the charge of conspiracy and the common plan. The British jurists drew up evidence of crimes against peace while the French and Soviet respectively presented indictments for war

\footnotetext{
${ }^{24}$ Ibid., 33- 34, 66- 67.

${ }^{25}$ John Q. Barrett, "Raphaël Lemkin and 'Genocide' at Nuremberg, 1945-1946," in The Genocide Convention Sixty Years after its Adoption, eds. Christoph Safferling and Eckart Conze (The Hague: Asser Press, 2010), 35-54, here 36-42; Hilary Earl, "Prosecuting Genocide before the Genocide Convention: Raphaël Lemkin and the Nuremberg Trials, 1945-1949," Journal of Genocide Research 15, no. 3 (2013), 322.

${ }^{26}$ Kim C. Priemel, The Betrayal: The Nuremberg Trials and the German Divergence (Oxford: Oxford University Press, 2016), 243.

${ }^{27}$ Ibid., 297; Paul Weindling, "Victims, Witnesses, and the Ethical Legacy of the Nuremberg Medical Trial," in Reassessing the Nuremberg Military Tribunals. Transitional Justice, Trial Narratives, and Historiography, eds. Kim C. Priemel and Alexa Stiller (New York: Berghahn 2012), 74-103, here 78.

${ }^{28}$ See Barrett, Raphä̈l Lemkin, 44-45.

${ }^{29}$ See ibid., 41-44, 53; Earl, Prosecuting Genocide, 323; Philippe Sands, East West Street. On the Origins of Genocide and Crimes against Humanity (London: Weidenfeld \& Nicholson, 2016), 185, 187, 298.

${ }^{30}$ See Daniel Marc Segesser and Myriam Gessler, "Raphaël Lemkin and the International Debate on the Punishment of War Crimes (1919-1948)," Journal of Genocide Research 7 (2005), 463; Jonathan Bush, "'The Supreme... Crime' and Its Origins: The Lost Legislative History of the Crime of Aggressive War," Columbia Law Review 120 (2002), 2368; Anson Rabinbach, "The Challenge of the Unprecedented - Raphaël Lemkin and the Concept of Genocide," Simon Dubnow Institute Yearbook 4 (2005), 410; John Cooper, Raphaël Lemkin and the Struggle for the Genocide Convention (Basingstoke: Palgrave Macmillan, 2008), 62-75.

${ }^{31}$ But they were able to do so in the course of the evidentiary process against the individual defendants and the organizations. The accused organizations were: the Reich Cabinet, the Leadership Corps of the Nazi Party, the SS including the SD (Sicherheitsdienst, Security Services), the Gestapo (Geheime Staatspolizei, Secret State Police), the SA, and the General Staff and the OKW (Oberkommando der Wehrmacht, High Command of the German Armed Forces).
} 
crimes in the West and East to the trial. ${ }^{32}$ The reasoning of the charges of crimes against humanity was provided by all four prosecution authorities in conjunction with their respective other charges. This division of labor has so far received little attention in existing research literature, but it helps to clarify why the mass murder of the Jews was almost exclusively linked to the charge of conspiracy or the crime of aggressive war by the American and British prosecutors as well as why the mass murder was often secondary in the prosecution.

After the questioning the defendants about their plea of guilty, Jackson began his opening statement by arguing the charge of conspiracy. It was the morning of the second day of the trial, November 21, 1945, when Jackson declared: "It is my purpose to show a plan and design, to which all Nazis were fanatically committed, to annihilate all Jewish people." ${ }^{\prime 33}$ Anti-Semitism, which he regarded as the basis of the persecution and extermination of the Jews, was not only directed against the Jews, but also against other nations in order to break resistance through division, he explained. Moreover, the practical experience of the extermination of the Jews had led the Nazis to implement "similar measures against Poles, Serbs, and Greeks." ${ }^{34}$ However, Jackson also made clear his assumption that the mass murder was directed against the Jews as such. He stated: "The avowed purpose was the destruction of the Jewish people as a whole, as an end in itself, as a measure of preparation for war, as a discipline of conquered peoples." ${ }^{35}$ Jackson also emphasized the seriousness of the crime: "History does not record a crime ever perpetrated against so many victims or one ever carried out with such calculated cruelty." ${ }^{36}$ Jackson held not only the party leaders and the SS responsible for the extermination, but also the Wehrmacht, and ministry officials. ${ }^{37}$ He saw not only calculation, but intention behind the persecution and murder of the Jews. He thus attached a historical singularity to the mass murder of European Jews.

Michael Marrus has already referred to Jackson's functional interpretation of anti-Semitism. ${ }^{38}$ Recent research has shown that the works of Franz L. Neumann, Otto Kirchheimer, and Herbert Marcuse influenced Jackson's presentation. Neumann was a lawyer and political scientist, Kirchheimer a constitutional lawyer, Marcuse a philosopher and social scientist. The three GermanJewish emigrants had a similar background: they were politically social democratic or socialist. Before 1933, all had had close scientific ties to two important academics who later legitimized the Nazi regime: Neumann and Kirchheimer to Carl Schmitt, Marcuse to Martin Heidegger. All three left Germany early in 1933 and quickly came into contact with Max Horkheimer's exiled Institute for Social Research. During the Second World War, all three contributed their scientific expertise to the Research \& Analysis Branch of the Office for Strategic Services (OSS) and taught at various US universities. The papers of the OSS served Jackson's team as important sources of information and interpretation..$^{39}$ Neumann's work Behemoth on the structures of the Nazi regime, first published in 1942, revised in 1944, served as a guide for the US prosecution in the IMT, but above all in the NMT trials to decipher the functioning of the Nazi rule. ${ }^{40}$ Neumann's structural perspective on the

\footnotetext{
32 See Jackson, 21 Nov 1945, IMT, II, 119; Alderman, 3 Dec 1945, IMT, III, 35; Maxwell-Fyfe, 8 Jan 1946, IMT, IV, 527. See also Irina Schulmeister-André, Internationale Strafgerichtsbarkeit unter sowjetischem Einfluss: Der Beitrag der UdSSR zum Nürnberger Hauptkriegsverbrecherprozess (Berlin: Duncker \& Humblot, 2016), 354.

${ }^{33}$ Jackson, 21 Nov 1945, IMT, II, 118.

${ }^{34}$ Ibid.

${ }^{35}$ Ibid., 119

${ }^{36} \mathrm{Ibid}$.

${ }^{37}$ Ibid., 118-127.

${ }^{38}$ Michael R. Marrus, “The Holocaust at Nuremberg," Yad Vashem Studies 26 (1998), 14-15.

${ }^{39}$ Otto Böhm and Rainer Huhle, “'Die wahre Klägerin vor den Schranken dieses Gerichts ist die Zivilisation.' Zur Eröffnungsrede des amerikanischen Hauptanklägers Robert H. Jackson," in Das Internationale Militärtribunal von Nürnberg 1945/46. Die Reden der Hauptankläger neu gelesen und kommentiert, ed. Nürnberger Menschenrechtszentrum (Hamburg: CEP Europäische Verlagsanstalt, 2015), 21-59, here 28-31, 46-47.

${ }^{40}$ Franz L. Neumann, Behemoth. The Structure and Practice of National Socialism, 1933-1944, 2nd ed., (Toronto: Oxford University Press, 1944). For Neumann's influence on the Nuremberg Military Tribunals see also Joachim Perels, "Fast vergessen: Franz L. Neumanns Beitrag zur Konzipierung der Nürnberger Prozesse. Eine Erinnerung aus Anlaß seines 100. Geburtstages," Kritische Justiz 34 (2001), 117-125; Kim C. Priemel and Alexa Stiller, “Nuremberg's Narratives. Revising the Legacy of the 'Subsequent Trials'," in Reassessing the Nuremberg Military Tribunals. Transitional Justice,
} 
persecution and murder of Jews later found its way into early Holocaust research through his PhD student Raul Hilberg. ${ }^{41}$

On December 13, 1945, Major William F. Walsh, assistant prosecutor for the United States, introduced evidence of the extent to which the crimes against the Jews were connected with the planning, preparation, start, and conduct of wars of aggression, thereby linking the persecution and extermination of the Jews in the first two charges ${ }^{42}$ Walsh presented only documents and did not call any witnesses, Jewish survivors or Jewish experts, who were present at Nuremberg. He brought the interpretation to court that the Europe-wide "annihilation of the Jewish people" had been the "ultimate objective of the Nazi Party" from the very beginning. ${ }^{43}$ The destruction of the Jews, so Walsh, was "carried out continuously, deliberately, intentionally, and methodically by the Nazis." ${ }^{44}$ In the further course of the argument, he presented documents on the ghettoization of the Jewish population of Central Eastern Europe, on the intended starvation of the people in the ghettos, on the destruction of the Warsaw ghetto, on mass executions in the Baltic States, Belarus and Ukraine, on the use of gas vans, the deportation of Dutch Jews, and the mass murder of Jews in the extermination camps Auschwitz and Treblinka. ${ }^{45}$ Finally, Walsh put the number of Jewish victims at 6 million for the first time, following the statement of Wilhelm Hoettl [Höttl], a former employee of the Reich Security Main Office. Höttl stated in an affidavit that Adolf Eichmann had personally testified to him that 4 million Jews had been murdered in camps and 2 million Jews had been executed by mass shootings during the war. ${ }^{46}$

Walsh had received support from Jacob Robinson, director of the Institute of Jewish Affairs at the American Jewish Congress, in compiling the immense evidence. ${ }^{47}$ From Robinson's perspective, Walsh had accurately and extensively presented the "Jewish Case" in court, and the president of the American Jewish Congress, Stephen S. Wise, thanked Walsh "in the name of American Jewry." ${ }^{48}$ This cooperation between Walsh and Robinson was one of the strongest examples of the participation of Jewish institutions in the Nuremberg Trials, although not the only one. The French and Soviet prosecution also received evidence and legal support from Jewish organizations.

Sir David Maxwell-Fyfe made only brief remarks on the persecution of the Jews as part of British evidence on the second charge of crimes against peace. They all referred to the German Foreign Office, especially to the accused Joachim von Ribbentrop. He presented evidence of a forced emigration policy of Jews from Germany and Austria. ${ }^{49} \mathrm{He}$ did not explicitly mention crimes against humanity during his opening statement. Although the UK Prosecution also had a very prominent

Trial Narratives, and Historiography, eds. Kim C. Priemel and Alexa Stiller (New York: Berghahn, 2012), 6-8; Priemel and Stiller, NMT.

${ }^{41}$ Raul Hilberg, The Destruction of the European Jews (New York: Harper \& Row, 1961). At the same time Wolfgang Scheffler, PhD student of Ernst Fraenkel, who had worked together with Neumann in the early 1930s, developed a similar political science-based approach to Holocaust research. See Wolfgang Scheffler, Die Judenverfolgung im Dritten Reich: 1933-1945 (Berlin: Colloquium Verlag, 1960). Hilberg and Scheffler were the most influential historians for newer Holocaust research since the 1990s. This political-structural perspective on the persecution and extermination of the European Jews is erroneously referred to today as 'perpetrator research.'

${ }^{42}$ Walsh, 13 Dec 1945, IMT, III, 519. See also Telford Taylor, Anatomy of the Nuremberg Trials: A Personal Memoir (New York: Knopf, 1992); Donald Bloxham, Genocide on Trial. War Crimes Trials and the Formation of Holocaust History and Memory (Oxford: Oxford University Press, 2001), 104-105; Laura Jockusch, "Justice at Nuremberg? Jewish Responses to Nazi War-Crime Trials in Allied-Occupied Germany," Jewish Social Studies 19, no. 1 (2012), 115-116.

${ }^{43}$ Walsh, 14 Dec 1945, IMT, III, 551.

${ }^{44}$ Ibid., 573.

${ }^{45}$ Ibid., 589-597, 614-634.

${ }^{46}$ Ibid., 634-644. See also Alexa Stiller, “Die Nürnberger Prozesse und der Holocaust. Frühe Interpretationen zur Verfolgung und Vernichtung der europäischen Juden," Einsicht 14 (2015), 20. Höttl contacted the OSS before the end of the war and later worked for the Counter Intelligence Corps (CIC). It can be assumed that he was never charged for this reason and also did not have to appear personally in court in Nuremberg.

${ }^{47}$ Michael R. Marrus, "A Jewish Lobby at Nuremberg: Jacob Robinson and the Institute of Jewish Affairs, 1945-46," Cardozo Law Review 27 (2006), 658, 1664.

${ }^{48}$ Jewish Telegraphic Agency, "Nuremberg Prosecutor Who Prepared ‘Jewish Case' Warns Against Public Apathy After Trial," February 24, 1946.

${ }^{49}$ Maxwell-Fyfe, 9 Jan 1946, IMT, V, 18-19. 
adviser at its side: Hersh Lauterpacht, Whewell Chair of International Law at the University of Cambridge. Lauterpacht's influence on the triad of prosecutable crimes under the IMT Charter had been decisive: the division into crimes against peace, war crimes, and crimes against humanity was due to him. Lauterpacht was also the creator of the crimes against humanity. ${ }^{50}$ This raises a question: How did the British prosecution barely mention the extermination of the European Jews, as Donald Bloxham has pointed out, but have an eminent international jurist at its side? ${ }^{51}$

This was due to the already mentioned division of the four charges to the prosecution authorities, whereby the British was mainly responsible for proving the crimes against peace. Though all four teams of prosecutors had reserved the right to hold evidence parallel to the charges of crimes against humanity, the close cooperation of the British with the Americans ${ }^{52}$ meant that Sir Hartley Shawcross' team's opening statement did not go into depth in the course of Walsh's presentation of evidence on the Jewish Case. On the other hand, it should not be forgotten that the entire concept of the new offense of crimes against humanity and its application in the IMT trial was primarily tailored to the persecution and extermination of the European Jews. Lauterpacht had created an element of offense under international criminal law that made it possible to prosecute violence against civilians far away from acts of war-without explicitly referring in the legal text to a national, ethnic, or religious group, even if the persecution and extermination of the Jews was the implicit object in 1945/1946. If one now follows Bloxham's thesis that the British prosecution wanted to minimize the Jewish Case in Nuremberg, the originally broadly conceived and contextualizing concept of genocide by Lemkin offered an alternative to the crimes against humanity. I will elaborate further on this point by reference to Shawcross's closing statement.

The French prosecution referred to the policy of extermination of European Jews as part of its evidence of the war crimes committed by the accused in Western Europe. The witness Marie Claude Vaillant-Couturier, who was imprisoned in the Auschwitz-Birkenau camp from January 1943 on, was the first survivor of a German concentration camp to give testimony during the Nuremberg trial. She had been brought to Auschwitz because of her membership in the Résistance, but she could nevertheless report in great detail about the conditions in the Birkenau camp, the treatment of Jewish women and children, the selection at the ramp of Jews from France, Greece, and Hungary, and the mass gassings of Jews and Sinti \& Roma. She had also been transported to the women's concentration camp in Ravensbrück in 1944 and could also speak about the human experiments on Polish women that took place there (which were later tried in the Nuremberg Medical trial), and on the executions and mass deaths of Hungarian Jewish women and children interned under extremely harsh conditions in Ravensbrück. ${ }^{53}$ Vaillant Couturier thus brought the persecution and murder of women and children in general and of Jewish women and children in particular to the public's attention. The two other concentration camp survivors who were called to the stand by the French prosecution also reported particularly bad treatment of the Jewish camp inmates. A former prisoner of a POW camp near Lviv testified as an eyewitness to the existence of deportation trains with Jews from all over Europe and to the executions of Jews in Lemberg. ${ }^{54}$

The French prosecutors, unlike the Americans and the British, had deliberately built their evidence on testimonies from victims. ${ }^{55}$ Charles Dubost, the French deputy chief prosecutor, presented an interpretation of the mass murder of the Jews in the camps, which differed significantly from the American perspective: "These camps were merely a means of realizing the policy of

\footnotetext{
${ }^{50}$ Martti Koskenniemi, "Hersch Lauterpacht and the Development of International Criminal Law," Journal of International Criminal Justice 2, no. 3 (2004), 810-825; Ana Filipa Vrdoljak, "Human Rights and Genocide: The Work of Lauterpacht and Lemkin in Modern International Law," The European Journal of International Law 20, no. 4 (2010), 1189.

${ }^{51}$ Bloxham, Genocide on Trial, chapter 2.

${ }^{52}$ They partly alternated in their argumentation and also spoke of a "joint presentation." See Alderman, 3 Dec 1945, IMT, III, 35; Shawcross, 4 Dec 1945, IMT, III, 145; Alderman, 10 Dec 1945, IMT, III, 368.

${ }^{53}$ Vaillant-Couturier, 28 Jan 1946, IMT, VI, 210-230.

${ }^{54}$ Victor Dupont was in Buchenwald, IMT, VI, 242-260; François Boix in Mauthausen, IMT, VI, 270-278; Paul Roser was in a prison camp in Rawa-Ruska close to Lviv, IMT, VI, 288-301.

${ }^{55}$ For reasons of time, therefore, they did not read out their evidence documents such as the Americans and the British in detail, but only named the numbers of the evidence.
} 
extermination which Germany had pursued ever since the National Socialists seized power. This policy of extermination would lead, according to Hitler, to installing 250 million Germans in Europe in the territories adjoining Germany, which constituted her vital space." ${ }^{\prime 56} \mathrm{He}$ continued: "The organization of these camps was further intended to exterminate all unproductive forces which could no longer be exploited by German industry, and which in general might hinder Nazi expansion." ${ }^{\prime 57}$ In line with its responsibility for bringing crimes against Jews from Western Europe to trial, the French prosecution also dealt with the circumstances of the deportations of Jews from Denmark, the Netherlands, and France to the ghettos, concentration and extermination camps in the East. ${ }^{58}$ Edgar Faure, another French counsel, came to the conclusion:

Such a large undertaking as the deportation of so many Jews required the intervention of many different administrative services, and we see here that the success of this enterprise depended on the reorganization of transport on the responsibility of the Reich Ministry of Transportation. It is certain that a ministerial department of this kind, which is above all a technical department, intervened to help carry out that general enterprise of deportation. ${ }^{59}$

Although he had previously quoted a deportation order signed by Adolf Eichmann, Faure did not succumb to the temptation to identify a single person as the main culprit. How could it be that a French prosecutor presented such elaborate historical analysis in the courtroom? Quite simply, Faure had a historian at his side who had already started working on the documentation of Nazi crimes, especially those directed against Jews in France during the war, Léon Poliakov ${ }^{60}$ As a child of a Jewish-Russian emigrant family that fled the Soviet Union after the October Revolution, Poliakov grew up in France. After being held as prisoner of war in 1940, he joined the Résistance and co-founded the Centre de Documentation Juive Contemporaine in 1943. The center collected documents on the persecution of the Jews in France. In 1945, Poliakov and one of his colleagues, Joseph Billig, were asked to accompany the French delegation to the IMT. ${ }^{61}$ There, Poliakov worked closely with Faure who was also a former member of the Résistance. Faure's interpretation of the functioning of the Nazi extermination policy bore the hallmarks of Poliakov's broader perspective on the structures of persecution. ${ }^{62}$

The Soviet prosecution was of the opinion that the German population had been deliberately blinded by Nazi propaganda. The Soviet chief prosecutor General Roman A. Rudenko emphasized the "German fascist race theory" as the basis of the crimes. He viewed this as the fundamental justification for the war of aggression: "In such manner, the function of racism was to justify the conspiracy-to fulfill the predatory aims of the German imperialistic clique." ${ }^{63}$ Instead of a "totalitarian system" like the Western allies, the Soviet representatives spoke of a "fascist system." Instead of "expansion" and "colonization," they spoke of "imperialism." In the eyes of the Soviet prosecution, the aims of the Nazi regime had been primarily economic. ${ }^{64}$ Rudenko interpreted them in this fashion:

\footnotetext{
${ }^{56}$ Dubost, 29 Jan 1946, IMT, VI, 324.

${ }^{57}$ Ibid., 327.

${ }^{58}$ See ibid., 321-328.

${ }^{59}$ Faure, 5 Feb 1946, IMT, VII, 38.

${ }^{60}$ See Alexa Stiller, "Historians Behind the Scenes: Léon Poliakov and the French Prosecution at the International Military Tribunal in Nuremberg," (presentation, Amsterdam, November 30, 2016), NIOD Institute for War, Holocaust, and Genocide Studies.

${ }^{61}$ See Laura Jockusch, Collect and Record! Jewish Holocaust Documentation in Early Postwar Europe (New York: Oxford University Press, 2013), 63-65; Lisa Moses Leff, The Archive Thief: The Man Who Salvaged French Jewish History in the Wake of the Holocaust (New York: Oxford University Press, 2015), 107-108.

${ }^{62}$ His book on the destruction of Europe's Jews was published in French in 1951 and in English in 1954, see Léon Poliakov, Harvest of Hate. The Nazi Program for the Destruction of the Jews of Europe, reprinted (New York: Holocaust Library, 1986).

${ }^{63}$ Rudenko, 8 Feb 1946, IMT, VII, 152.

${ }^{64}$ Ibid., 154.
} 
As a result of fascist propaganda and the whole system of measures cultivated by the German State, the German mind was systematically poisoned by the fumes of chauvinism and hatred of mankind... The criminal conspiracy aimed at the establishment of a predatory New Order in Europe. This New Order was a regime of terror by which, in the countries seized by the Hitlerites, all democratic institutions were abolished and all civil rights of the population were abrogated, while the countries themselves were plundered and rapaciously exploited. The population of these countries, and of the Slav countries above all others-especially Russians, Ukrainians, Belarussians, Poles, Czechs, Serbians, Slovenes, Jews-were subjected to merciless persecution and mass extermination." 65

Although the French prosecution emphasized German economic interests as war objectives more strongly than the American and British, the Soviet prosecution, in contrast to the French, was initially less willing to consider Jewish persecution and extermination pressure as more intense than for the rest of the civilian population of Eastern Europe. I say "initially" because this was true for the chief prosecutor, but not for the entire Soviet prosecution, as will be shown. In his opening statement, Rudenko spoke generally of civilians when he discussed mass shootings from the Baltic countries to the Caucasus. He did not explicitly mention the fact that almost exclusively Jewish families were affected, ${ }^{66}$ and when he did, he set the murder of the "Slavic and Jewish peoples" on the same level ${ }^{67}$ At one point, however, even Rudenko broke through this equalization of the victims: "The fascist conspirators planned the extermination to the last man of the Jewish population of the world and carried out this extermination throughout the whole of their conspiratorial activity from 1933 onwards." ${ }^{\prime 8}$ Similarities to Jackson's and Walsh's intentionalist interpretation are clearly recognizable.

When the Soviet prosecution came to provide evidence of crimes against humanity, the picture changed with respect to the Jewish Case. Lev N. Smirnov dealt with the charges of "crimes against the peaceful population of the USSR, Czechoslovakia, Poland, and Yugoslavia" and in particular the murder of Jews east of Germany. ${ }^{69}$ Smirnov's arguments on this point took four days at the court. He described in detail the murder of 3 million Polish Jews in the Generalgouvernement under the responsibility of Hans Frank (the mobile gas vans, the deportations from the ghettos to the extermination camps, and the murders by gas in Auschwitz, Treblinka and Sobibor). ${ }^{70}$ Smirnov said he would not read anti-Semitic remarks from Göring, Himmler or other Nazis in the courtroom because: "In the Eastern European countries all the anti-Semitism of the Hitlerites was put into full effect and mostly in one way only-in the physical extermination of innocent people." ${ }^{\prime 11}$ Accordingly, as part of the evidence of the persecution and extermination of Jews in Eastern Europe, the Soviet prosecution called the following survivors to the witness stand: Abram Gerzevitch Suzkever [Sutzkever], who survived the ghetto in Vilnius, the Polish woman Severina Shmaglevskaya, who survived the Auschwitz-Birkenau extermination camp, and Samuel Rajzman, Jewish-Polish survivor of the Treblinka extermination camp. ${ }^{72}$ Smirnov quoted the report of the Polish commission of inquiry, which cited the number of people murdered in Treblinka for the first time at 781,000. He also gave the results of the Polish commission of inquiry on the mass murder by gas vans in Kulmhof. ${ }^{73}$ Quoting from the Polish and Czechoslovak commission reports, he stated

\footnotetext{
${ }^{65} \mathrm{Ibid} .$, 153. Of course, he did not mention Estonians, Latvians, and Lithuanians, the populations of countries that the USSR itself had annexed, lost, and re-annexed during and after the Second World War.

${ }^{66}$ Ibid., 170-173.

${ }^{67}$ Ibid., 191.

${ }^{68}$ Ibid., 192.

${ }^{69}$ Smirnov, 14-15 and 18-19 Feb 1946, IMT, VII, 437-602; Smirnov, 25-27 Feb 1946, IMT, VIII, 238-344.

${ }^{70}$ Smirnov, 15 Feb 1946, IMT, VII, 470. In the IMT mistakenly “Sobibur" see Smirnov, 19 Feb 1946, IMT, VII, 576.

${ }^{71}$ Smirnov, 26 Feb 1946, IMT, VIII, 294.

72 Suzkever, Shmaglevskaya, and Rajzman, 27 Feb IMT, VIII, 302-308, 317-322, 324-329. See also Jockush, Justice at Nuremberg?, 108-109, 120. Earlier, Smirnov had already quoted another Treblinka survivor, Jacob Vernik. See Smirnov, 25 Feb 1946, IMT, VIII, 239-240.
} 
that the "Hitlerites"74 had murdered 3 million Polish Jews and 118,000 Czechoslovakian Jews. ${ }^{75}$ It was striking that the Soviet prosecutors did not explicitly name Soviet Jews as victims.

The Soviet prosecution chose the same strategy as the French one: instead of an extensive presentation of original German documents, they had survivors testify about the Nazi crimes. There was another similarity to the French prosecution: The Polish, Czechoslovak, and Yugoslav delegations assisted her in an advisory function. Among the members of the Polish delegation were also Holocaust survivors including historians Philip Friedman and Josef Wulf. Both of them worked for the Central Jewish Historical Commission in Poland. ${ }^{76}$ But also the Soviet writer, war propagandist, and early chronicler of the murder of Soviet Jews, Ilya Ehrenburg, came to Nuremberg for the IMT trial. ${ }^{77}$ What influence Ehrenburg, Friedman, Wulf, and the national delegations had in the elaboration of Soviet reasoning has not yet been sufficiently researched..$^{78}$

In conclusion, the Soviet prosecution dealt intensively with the persecution and extermination of Jews in Eastern Europe. It described the conditions in the ghettos, the deportations, the methods of murder, the extermination camps, and named many places of mass executions. As evidence, the jurists brought the reports of early commissions documenting the Nazi crimes and eyewitness accounts of the liberation of the camps. Crucially, the Soviet prosecution was the only one of the four prosecuting authorities to call Jewish Holocaust survivors to the stand.${ }^{79}$ Despite the designation of Jewish victims in the occupied territories of the USSR as "Soviet citizens," these findings indicate a need to reassess the narrative that the Soviet prosecution was not interested in addressing the mass murder of the Jews in Nuremberg.

\section{Closing Statements of the Four Prosecutions}

After the general line of argument on the four charges and against the individual defendants had been completed (and only the cases against the six organizations charged with criminality were still pending), the four main prosecutors gave their closing statements. Jackson began his speech on July 26, 1946, without mentioning Lemkin's concept of genocide. His main focusfollowing the division of the charges among the four allies-was the conspiracy of the accused and their common plan to prepare and implement the war of aggression. Jackson explained five

\footnotetext{
${ }^{73}$ Smirnow, 27 Feb 1946, IMT, VIII, 330. In the official German and English text Chełmno/Kulmhof is mistakenly referred to as Helmno. The Polish commission of inquiry estimated the number of persons murdered there at 340,000 . See Ibid., 330-331. Today, Alberti assumes that about 160,000 people were murdered there, see Michael Alberti, Die Verfolgung und Vernichtung der Juden im Reichsgau Wartheland, 1939-1945 (Wiesbaden: Harrassowitz, 2006), 451.

${ }^{74}$ The Soviets used this term to make it clear that not only Nazi Party members and not only Germans participated in the extermination policy.

${ }^{75}$ Smirnow, 26 Feb 1946, IMT, VIII, 299.

${ }^{76}$ David Cesarani, “Challenging the 'Myth of Silence': Postwar Responses to the Destruction of European Jewry," in After the Holocaust: Challenging the Myth of Silence, eds. David Cesarani and Eric J. Sundquist (London: Routledge, 2012$), 28$. For the Commission see also Jockusch, Collect, 90-94; Frank Beer et al, eds., Nach dem Untergang. Die ersten Zeugnisse der Shoah in Polen 1944-1947. Berichte der Zentralen Jüdischen Historischen Kommission (Berlin: Metropol, 2014).

${ }^{77}$ Abraham Sutzkever also contributed an eyewitness report to the Black Book on the murder of Jews on the territory of the Soviet Union, which Ehrenburg published together with Vasily Grossman. See Ilya Ehrenburg and Vasily Grossman, eds., The Black Book: The Ruthless Murder of Jews by German-Fascist Invaders Throughout the Temporarily-Occupied Regions of the Soviet Union and in the Death Camps of Poland During the War of 1941-1945 (New York: Holocaust Library, 1981); Jockusch, Justice at Nuremberg?, 119-120.

${ }^{78}$ Schulmeister-André's book is the first comprehensive analysis of the Soviet contribution to the IMT from a legal perspective. Francine Hirsch and Lilia Antipow are also working on comprehensive studies. See Schulmeister-André, Internationale Strafgerichtsbarkeit; Francine Hirsch, "The Soviet Union, the Nuremberg Trials, and the Politics of the Postwar Moment," in Political Trials in Theory and History, eds. Jens Meierhenrich and Devin O. Pendas (Cambridge, UK: Cambridge University Press, 2016), 157-183; Lilia Antipow, “’Die wahrhaft räuberischen Pläne der hitlerischen Angreifer gegen die Sowjetunion.' Zur Eröffnungsrede des sowjetischen Hauptanklägers Roman Rudenko," in Das Internationale Militärtribunal von Nürnberg 1945/46. Die Reden der Hauptankläger neu gelesen und kommentiert, ed. Nürnberger Menschenrechtszentrum (Hamburg: CEP Europäische Verlagsanstalt, 2015), 227-277.

${ }^{79}$ See also Annette Weinke, Die Nürnberger Prozesse (Munich: C.H. Beck, 2006), 50. In the course of the evidence against the SS as a criminal organization, the witness of the British prosecution Izrael Eizenberg was later called. Eizenberg and only one other person survived a mass shooting of 1,000 people near the Lublin-Majdanek concentration camp in October 1942. The questioning took less than five minutes. See Eizenberg, 7 Aug 1946, IMT, XX, 484-485. See also Jockusch, Justice at Nuremberg, 15.
} 
crime complexes related to his evidence: first, the seizure of power and the establishment of a "police state;" secondly, the "preparation and waging of wars of aggression;" thirdly, war crimes, in particular the murder of Western allied POWs and the civilian population of the Soviet Union; fourthly, the "enslavement and plunder of the population in the occupied countries;" and fifthly, the "persecution and extermination of Jews and Christians." 80 The crimes committed by the Nazis could not be considered individually, he said. At the same time, he made clear where his priority lay: "The central crime in this pattern of crimes, the kingpin which holds them all together, is the plot for aggressive wars." ${ }^{81}$ The assumption of the "Nazi Master Plan," which he did not explicitly mention here, but which appeared in his later report, ${ }^{82}$ was probably based on the work of Herbert Marcuse, who had written a memorandum entitled Nazi Plans for Dominating Germany and Europe: The Nazi Master Plan in August 1945 as part of his work with the OSS. ${ }^{83}$

Nevertheless, Jackson also clearly included the mass murder of the Jews: "The Nazi movement will be of evil memory in history because of its persecution of the Jews, the most far-flung and terrible racial persecution of all time." ${ }^{84}$ Jackson believed that an economic motive supported a fanatical anti-Semitism, which eliminated Jewish pacifism and robbed Jews of their assets in order to financing armament. ${ }^{85} \mathrm{He}$ particularly emphasized one person as main perpetrator: "Adolf Eichmann, the sinister figure who had charge of the extermination program." ${ }^{86}$ In this context he also named the Einsatzgruppen of the Security Police and the Security Service (SD) as responsible for the mass shootings of the Jews in the occupied territories of the Soviet Union. The contradictions in his statement can only be resolved if it is assumed that Jackson regarded the punishment of the war of aggression as the most important aspect of the Nuremberg trial from a legal and international criminal law standpoint and, at the same time, was personally and morally moved by the mass murder of the European Jews. What is still irritating is the focus on the SS and the SD as perpetrator organizations and on Eichmann as a kind of main perpetrator of the Holocaustbecause the evidence presented in the course of the trial also supported other conclusions. The emergence of this narrative was due to the legal approach to organizational crime, as I will discuss later. The narrowing of the perpetrators of the extermination of the European Jews by the US prosecution should nevertheless have an impact on the subsequent NMT trials in Nuremberg.

The British prosecution had undergone different developments concerning the genocide concept over the months. Whether this was due to Lemkin meeting Maxwell Fyfe at the end of June 1946 and campaigning for his concept ${ }^{87}$ or, as I have already indicated above, to the fact that the genocide concept was broader and more suitable for British politics, is difficult to say. Shawcross, the chief British prosecutor, dealt in his closing statement with both the mass violence against civilians during the Second World War and the extermination of Jews. In that setting, he used Lemkin's concept. Instead of depicting the mass murder of the European Jews in its peculiarity, like Jackson, Shawcross included it in the overall crimes of the Nazi regime, which (according to the figures he presented) claimed at least 12 million victims, six million of them Jews. Nevertheless, he coined a memorable phrase for the murders in the gas chambers, which he defined as "some mass production industry." ${ }^{\prime 8} \mathrm{He}$ also assessed the perpetrators of the mass executions in the occupied territories of the Soviet Union differently from Jackson:

\footnotetext{
${ }^{80}$ Closing statement, Jackson, 26 July 1946, IMT, XIX, 400-406.

${ }^{81}$ Ibid. 406. Cf. Robert H. Jackson, Report of Robert H. Jackson, United States Representative to the International Conference on Military Trials, London 1945 (Washington, D: 1949), 48; Priemel and Stiller, Wo 'Nürnberg' liegt.

${ }^{82}$ Jackson, Report of Robert H. Jackson, 48. The "master plan" assumption was used in the trial by Alderman, 23 Nov 1945, IMT, II, 248; Drexel A. Sprecher, 23 Jan 1946, IMT, VI, 72.

${ }^{83}$ See Böhm and Huhle, Die wahre Klägerin, 46-47. For Marcuse's functional understanding of anti-Semitism in Nazi Germany, see e.g. Herbert Marcuse, "Der Kampf gegen den Liberalismus in der totalitären Staatsaufassung," in Faschismus und Kapitalismus. Theorien über die sozialen Ursprünge und die Funktion des Faschismus, ed. Wolfgang Abendroth (Frankfurt am Main: Europäische Verlagsanstalt, 1967), 39-74.

${ }^{84}$ Closing statement, Jackson, 26 July 1946, IMT, XIX, 404.

${ }^{85}$ Ibid., 404- 405, 414.

${ }^{86}$ Ibid., 405.

${ }^{87}$ On 26 Aug 1946 Lemkin wrote another letter to Maxwell Fyfe. See Barrett, Raphaël Lemkin, 48-49, 51.

${ }^{88}$ Shawcross, 26 July 1946, IMT, XIX, 433. On the classification of the mass murder of Jews in all war crimes against civilians and crimes against humanity, see also ibid., 466- 467, 507.
} 
These actions were not only the work of the SS and Himmler. They were carried out in co-operation with the army commanders with the full knowledge of Keitel and Jodl and, indeed, because every soldier fighting in the East must have known about them, with the knowledge also of every member of the Government and of the commanders of its Armed Forces. $^{89}$

Shawcross regarded the extermination of the Jews as an important objective of the Nazi regime, which was, however, equally important with the aims of expansion and "European domination." 90 In doing so, Shawcross somewhat inconsistently emphasized the mass murder of the Jews as something unique, on the one hand, and, on the other, refrained from emphasizing any particular group of victims: "Nazi total war was also a war against civilian populations, against whole peoples." 91 Shawcross also ascribed other techniques of violence and oppression to the Nazis' overarching goal of colonizing conquered territories with Germans as a new "living space." Therefore, he explicitly used Lemkin's original concept of genocide:

Genocide was not restricted to extermination of the Jewish people or of the gypsies. It was applied in different forms to Yugoslavia, to the non-German inhabitants of Alsace-Lorraine, to the people of the Low Countries and of Norway. The technique varied from nation to nation, from people to people. The long-term aim was the same in all cases. The methods followed a similar pattern: First a deliberate program of murder, of outright annihilation. This was the method applied to the Polish intelligentsia, to gypsies, and to Jews... The defendants and their confederates also used methods of protracted annihilation, the favorite being to work their victims to death... Another favorite technique of extermination was by starvation... The method applied in Alsace was deportation... The Nazis also used various biological devices, as they have been called, to achieve genocide. They deliberately decreased the birthrate in the occupied countries by sterilization, castration, and abortion, by separating husband from wife and men from women and obstructing marriage. ${ }^{92}$

He also described the murder of about 275,000 mentally ill persons as a crime within the framework of this "policy of genocide." ${ }^{93}$ In his study on the Soviet position on the Genocide Convention, Anton Weiss-Wendt shows that even later in the negotiations on the content of the Convention, the British and Soviet delegations regarded genocide as a comprehensive crime against population groups, which they necessarily located in the context of the war of aggression. This shared view in 1947 came from the exchange the two prosecutions had during the IMT trial. ${ }^{94}$

The French prosecution also used the concept of 'genocide. ${ }^{\prime 95}$ With the "systematic extermination of millions of human beings," Nazi Germany had pursued the goals of expanding and conquering "living space" and the "gigantic plan of world domination." 96 When Auguste Champetier de Ribes, the French chief prosecutor, spoke of "extermination" and "annihilation" he meant, however, unlike Shawcross, explicitly murder or measures leading to death such as starvation. ${ }^{97}$ Dubost made it clear that the pursuit of these objectives (and thus also the application of the method of destruction) had been based on broad cooperation:

\footnotetext{
${ }^{89}$ Ibid., 503.

${ }^{90}$ Ibid., 438.

${ }^{91}$ Ibid., 494, see also 466-468.

${ }^{92}$ Ibid., 497- 498.

${ }^{93}$ Ibid., 515. See also Dan Stone, "Raphaël Lemkin on the Holocaust," Journal of Genocide Research 7 (2005), 539-550; A. Dirk Moses, "Lemkin, Culture, and the Concept of Genocide," in The Oxford Handbook of Genocide Studies, eds. Donald Bloxham and A. Dirk Moses (Oxford: Oxford University Press, 2010), 19-41.

${ }^{94}$ Weiss-Wendt, The Soviet Union, 25, 56-57.

${ }^{95}$ Champetier de Ribes, 29 July 1946, IMT, XIX, 531. See also Dubost, 29 July 1946, IMT, XIX, 550-551, 562, 564, 570. Cooper writes that Lemkin also knew the French judge Henri Donnedieu de Vabres from his time in Poland, see Cooper, Raphaël Lemkin, 17-18.

${ }^{96}$ Champetier de Ribes, 29 July 1946, IMT, XIX, 531, 532-533.

${ }^{97}$ Ibid. 533-534.
} 
Everything kept steady, everything was indissolubly united because totalitarian policy, total war, the preparation and direction of the campaign of extermination of peoples for the conquest of living space, implied the closest co-ordination and liaison between all the parts of the machine, between Police and Army; Foreign Affairs and Police and Army; Justice and Police; Economics and Justice; Universities and Propaganda and Police. ${ }^{98}$

This shows Poliakov's and Neumann's structural or institutional approach, which was used to describe the functioning of the Nazi regime and support the criminal prosecution of the perpetrators. According to the legal opinion of the French prosecuting authority, the legal constructs of "conspiracy or complicity" were not necessary at all because a "solidarity and the equal culpability of all in the crime" could be proven for every accused on the basis of fact:

1) The defendant occupied within the machinery of the State and the Party a position of eminence which endowed him with authority over one entire office or several. 2) The defendant complied with, if he did not conceive, the doctrine of the regime: Conquest of space by any means. 3) He personally played an active part in the political development of this doctrine. ${ }^{99}$

The French jurists thus presented a continental European legal opinion that differed from the Anglo-American one and distanced themselves from the conspiracy charge. This was one of the rare moments in the first international criminal proceedings in history in which the problem of merging civil law and common law legal systems became apparent. The French prosecution's view, both on the functioning of the Nazi regime and on the division of labor in implementing the extermination policy, can be seen as the most complex and elaborate interpretation on the mass violence of the Nazi regime put forward during the IMT trial. This interpretation was not intentionalist, for it neither needed a "plan" conceived at an early stage, nor a fanatical antiSemitism, an order by Hitler (Führerbefehl) to murder the Jews, or the construction of a "main perpetrator" such as Eichmann.

The interpretations of the Soviet prosecution were quite different especially because of its linguistic style. ${ }^{100}$ Rudenko addressed the connection between the direct perpetrators and the defendants, i.e. the upper echelons, in his closing statement as follows:

The defendants are responsible for every murder, for every drop of innocent blood shed by Hitler's hangmen, for between them and the direct perpetrators of the crimes, murders, tortures, there is a difference only in rank and scope of action. Those are the direct hangmen, and these are the principal hangmen, hangmen of a higher rank. ${ }^{101}$

The Soviet prosecution still sympathized with the Anglo-American legal construct of conspiracy, as it was able to declare the "fascist conspiracy" of the "criminal group" with "criminal aims." 102 The Soviet prosecution found a simple answer to the question of how anti-Semitic propaganda and the practice of the mass murder of the Jews had been connected:

One can consider Streicher as the actual 'spiritual father' of those who quartered the children of Treblinka. Had it not been for the Stürmer and its editor German fascism would not have

\footnotetext{
${ }^{98}$ Dubost also explicitly mentioned the participation of industrialists. See Dubost, 29 July 1946, IMT, XIX, 543-544. Instead, camp commanders like Kramer and Höss saw the French prosecution as "those who merely carried out the orders of the National Socialist State, who only played the part of hangman." Ibid., 568.

${ }^{99}$ Ibid., 549-550, also 561-562.

${ }^{100}$ Moreover, after the Iron Curtain speech by Churchill (5 March 1946), the German testimonies on the Katyn massacre (1 July 1946), and the apparently unsuccessful use of the IMT as a stage for Soviet ideology, the Soviet side was under strong pressure. See Claudia Weber, Krieg der Täter: die Massenerschiessungen von Katyń (Hamburg: Hamburger Edition, 2015), 290-354, 496-497; Schulmeister-André, Internationale Strafgerichtsbarkeit, 448-456; Weiss-Wendt, The Soviet Union.

${ }^{101}$ Rudenko, 29 July 1946, IMT, XIX, 573.

${ }^{102}$ Ibid., 579.
} 
been able to educate, at such short notice, those mass murder gangs who put into effect the criminal plans of Hitler and his thugs by murdering over 6 million European Jews. ${ }^{103}$

Contrary to popular opinion, Rudenko mentioned the persecution and extermination of the Jews in his closing remarks, very precisely and in detail in relation to the accused Ernst Kaltenbrunner. However, with regard to the victims of the mass murder of the Einsatzgruppen on Soviet soil, he again spoke indeterminately of "human beings," Belarussian "peasants," Belarussian "women and children," and "Soviet citizens" — but not of Jews. ${ }^{104}$

The Soviet prosecution tended to link Nazi "extermination of peoples" and "genocide" as well as economic "enslavement of nations" with fascism, capitalism, and imperialism. ${ }^{105}$ Rudenko reiterated these themes during his concluding statement on the charges against the organizations: "In reality the German fascists are not nationalists but imperialists, whose main and decisive aim was the seizure of foreign land so as to further the expansion of militant German capitalism." ${ }^{106}$ In Rudenko's closing statement, the ideological overload and Stalinist paranoia of the Soviet prosecution leadership is obvious. Although there are good reasons to define the trial before the IMT as a political trial, as Otto Kirchheimer and Judith Shklar did in the $1960 \mathrm{~s},{ }^{107}$ it was not a show trial following the example of the Moscow trials ten years earlier or the trial against antiCommunist Polish politicians and military officers led by Rudenko shortly before the beginning of the Nuremberg trial. Moreover, if a show trial was the intention of the Soviet prosecutors, they definitely did not succeed.

In summary, the four prosecutions emphasized different central motives and driving forces of the Nazi regime, had different definitions of the legal concepts of genocide and conspiracy, and understood the term extermination differently. At the same time, they agreed that the murder of European Jews during the war had been linked to the whole Nazi policy of violence and extermination. The decontextualization of the mass murder of the Jews and separation of this crime from the other Nazi crimes happened later.

Until then, the four prosecution representatives had mostly covered the perpetrators' circle very broadly. However, with the exception of the French, they presented a different picture in their closing statements on the accused organizations. There, each offered a separate explanation and reduced the number of perpetrators of the Holocaust. For example, the British prosecutor Maxwell-Fyfe proposed a simplified formula: "The system of exterminating Jewry was handled by SS." ${ }^{108}$ Thomas Dodd, a staff member of Jackson's team, also outlined a simple chain of command of the Final Solution from Göring to Heydrich and Himmler, to the SS, the SD and the Gestapo (namely Adolf Eichmann). Similar to Maxwell-Fyfe, Dodd declared: "In his [Himmler's] foul hands and those of his SS was placed the assignment for the complete destruction of the Jew." 109 Rudenko fully agreed with this view. He blamed the SS (specifically the Economic and Administrative Main Office of the SS) for the extermination camps Auschwitz and Majdanek and the Gestapo for Treblinka and Kulmhof: “Eichmann's plan for the extermination of the Jews in Europe, with the help of special extermination camps... originated in the Gestapo."110

\footnotetext{
${ }^{103}$ Ibid., 611.

${ }^{104}$ For example, ibid., 598-599. A direct mention of the Polish Jews, on the other hand, can be found in the prosecution's explanations to Frank see ibid., 607-609.

${ }^{105}$ Ibid., 570.

${ }^{106}$ Rudenko, 30 Aug 1946, IMT, XXII, 313.

${ }^{107}$ The discussion cannot be elaborated here. See Otto Kirchheimer, Political Justice. The Use of Legal Procedure for Political Ends (Princeton: Princeton University Press, 1961); Judith N. Shklar, Legalism: Law, Morals and Political Trials (Cambridge, MA: Harvard University Press, 1964); Priemel and Stiller, Nuremberg's Narratives, 3-4. See also Jens Meierhenrich and Devin O. Pendas, eds., Political Trials in Theory and History (Cambridge, UK: Cambridge University Press, 2016).

${ }^{108}$ Maxwell-Fyfe, 29 Aug 1946, IMT, XXII, 230.

${ }^{109}$ Dodd, 29 Aug 1946, IMT, XXII, 256.

${ }^{110}$ Rudenko, 30 Aug 1946, IMT, XXII, 342. Eichmann's activities during the war were mostly limited to the logistical aspects of deportations of Poles and Jews. In particular, he organized the deportations of Jews from Nazi occupied Western and Southeastern European countries to the Auschwitz-Birkenau extermination camp. He was neither
} 
This narrowing of the perspective was directly related to the concept of the IMT. First, the emphasis on conspiracy was responsible for placing the leaders of the regime and personalized chains of command at the center of attention. Secondly, it resulted from the emphasis on organizational crime, which inevitably led in the trial to place the SS, SD and Gestapo (as opposed to the four other organizations accused) at the center of the responsibility for mass violence-while neglecting the responsibility of other institutions.

\section{The Judgment of the IMT}

In their verdict, the Allied judges stated that the prosecution had extensively demonstrated the main objective of the Nazi regime, which in their opinion was the conquest of "living space." The atrocities and murders committed during the war were seen as consequences of this goal rather than aims in themselves. Despite this interpretation, which was close to Lemkin's original one, they did not mention the term genocide in their judgment (to Lemkin's disappointment ${ }^{111}$ ). Instead, they said:

The foregoing crimes against the civilian population are sufficiently appalling, and yet the evidence shows that at any rate in the East, the mass murders and cruelties were not committed solely for the purpose of stamping out opposition or resistance to the German occupying forces. In Poland and the Soviet Union these crimes were part of a plan to get rid of whole native populations by expulsion and annihilation, in order that their territory could be used for colonization by Germans. ${ }^{112}$

This makes it clear that the judges interpreted expulsion and extermination in the same contextjust as Lemkin had done in his study Axis Rule. However, the IMT trial failed to set a precedent by charging these crimes as 'genocide,' a decision that would have led the concept in a different direction than the Genocide Convention would two years later.

The sentence dealt in great detail with the persecution and extermination of the Jews. Here, the judges developed their own interpretation of the events and followed neither the intentionalist perspective suggested by Jackson nor the structuralist/functionalist perspective of the French prosecution. In the judgment, the description read as follows: Although Hitler had "threatened" the "extermination of the Jews" in early 1939, the "final solution" had not been planned until summer 1941 "shortly after the attack on the Soviet Union." The Einsatzgruppen were responsible for the murder of the Jewish population in the occupied territory of the Soviet Union. The tribunal was clear about the cooperation of the Einsatzgruppen with the Wehrmacht, but refrained from concrete accusations: "There is clear evidence that leaders of the Einsatzgruppen obtained the cooperation of Army commanders." ${ }^{113}$ The judges assumed that almost every single accused and every accused organization had been proven to be involved in the persecution and extermination of the Jews. However, they declared the Gestapo, SD, and SS as the primary perpetrators. ${ }^{114}$ With regard to the mass murder of the Jews in the extermination camps, the court's portrayal gradually overemphasized Eichmann's role. The verdict stated, "Adolf Eichmann, who had been put in charge of this program by Hitler." 115 In the course of the IMT trial, Eichmann had thus not only become the key witness to the number of victims of 6 million Jews through Höttl's affidavit, but also a direct recipient of Hitler's order. This was a fatal error, which led directly to the Eichmann trial in Jerusalem in 1961, but ultimately positively to a revitalization of the debate about the extermination of European Jews in justice and history.

responsible for the Kulmhof extermination camp, the Operation Reinhard extermination camps (Belzec, Sobibor,

Treblinka), nor for the mass shootings of the Einsatzgruppen in Eastern Europe. Cf. Christian Gerlach, The

Extermination of the European Jews (Cambridge, UK: Cambridge University Press, 2016).

${ }^{111}$ See Barrett, Raphaël Lemkin, 51-52.

${ }^{112}$ Judgment, 30 Sept 1946, IMT, I, 237.

${ }^{113}$ Ibid., 250.

${ }^{114}$ Ibid., 265, also 267, 270-272.

${ }^{115}$ Ibid., 252, see also 250, 265. 
Overall, the new concept of 'genocide' was used in the course of the IMT trial to describe a policy consisting of different crimes or 'techniques' and directed against different groups of victims. Defined in this way, the concept of 'genocide' was attributed to the motive of the conquest and colonization of 'living space' by the Germans rather than to the intention, later enshrined in the Genocide Convention, of destroying a national, ethnical or religious group per se. The prosecutors and judges had not seen the mass murder of the Jews as congruent with the concept of 'genocide' but as part of it.

\section{The Effects of the IMT on the NMT}

The concept of genocide was applied in several of the twelve subsequent trials before the solely American-led Nuremberg Military Tribunals (NMT). Aspects of the persecution and extermination of the Jews were addressed in all of these proceedings. Unlike the IMT trial, the NMT trials were based on Control Council Law No. 10 (CCL 10), in which the Charter of the IMT had been further developed and the category of crimes against humanity was redefined and gained independence; the causal nexus to crimes against peace or war crimes was dissolved. ${ }^{116}$ Crimes against humanity were now defined as: "Atrocities and offenses, including but not limited to murder, extermination, enslavement, deportation, imprisonment, torture, rape, or other inhumane acts committed against any civilian population, or persecutions on political, racial or religious grounds whether or not in violation of the domestic laws of the country where perpetrated." 117 Therefore, CCL 10 also made mass rape justiciable in international criminal law for the first time.

The Office of the Chief of Counsel of War Crimes (OCCWC), headed by Telford Taylor, applied a new concept called the 'institutional approach' during the NMT. It defined the twelve cases not by crime complexes (by which I mean, for example, forced labor, Aryanization, expulsion, etc.), but by crimes committed by certain institutions. There were two cases against the Wehrmacht, three against SS offices, three against industrial companies, one against a ministerial authority, two cases that concerned both the ministries and the SS or Wehrmacht, and one case, the Ministries trial, which consisted of groups of defendants thrown together, representatives of financial institutions, the Foreign Office and other ministries, but also of the SS. ${ }^{118}$ Neumann's analysis was unmistakably the guiding force structuring these processes. ${ }^{119}$

I will go in more detail by examining four cases: ${ }^{120}$ The Medical trial (Case 1) and the RuSHA trial (Case 8), which employed a broad definition of the concept of genocide; the Einsatzgruppen trial (Case 9), which was the only trial where the main focus was the mass murder of Jews, but specifically the mass shootings in the Baltic States, Eastern Poland, and the occupied territories of the Soviet Union; and the Ministries trial (Case 11), the last trial before the NMT, in which the interpretation of the mass murder of the Jews as a coherent enterprise limited to one group of perpetrators was elaborated most strongly.

Although the 'genocide' concept was used more prominently in the NMT than the IMT, Lemkin did not play a role; at the time, he focused on the UN Convention on Genocide. In the planning phase of the subsequent Nuremberg trials, however, he wrote two letters on 10 and 13 January 1946 to a member of Taylor's team, Col. David Marcus, and made detailed suggestions for the application of his concept in the coming trials. First, he emphasized the usability of the 'genocide' concept for the case of medical experiments, which he understood as "techniques of

\footnotetext{
${ }^{116}$ Lawrence Douglas, "From IMT to NMT. The Emergence of a Jurisprudence of Atrocity," in Reassessing the Nuremberg Military Tribunals. Transitional Justice, Trial Narratives, and Historiography, eds. Kim C. Priemel and Alexa Stiller (New York: Berghahn 2012), 282. Cf. Kevin Jon Heller, The Nuremberg Military Tribunals and the Origins of International Criminal Law (Oxford: Oxford University Press, 2011).

117 "Control Council Law No. 10," in Trials of War Criminals before the Nuremberg Military Tribunals under Control Council Law No. 10 (hereafter TWC), Volumes 1-15, October 1946 - April 1949 (Washington, DC: 1950-1953), vol. IV, xix.

${ }^{118}$ Priemel and Stiller, Nuremberg's Narratives, 6, 12; Jan Erik Schulte, "The SS as the 'Alibi' of a Nation? Narrative Continuities from the Nuremberg Trials to the 1960s," in Reassessing the Nuremberg Military Tribunals. Transitional Justice, Trial Narratives, and Historiography, ed. by Kim C. Priemel and Alexa Stiller (New York: Berghahn 2012), 140, $142,145$.

${ }^{119}$ See fn. 40.

${ }^{120}$ On the application of genocide in all trials, see Stiller, Semantics of Extermination.
} 
genocide." Secondly, he considered it also suitable to undermine the strategy of the defendants in the planned IG Farben trial. If the managers of IG Farben could be proven to be cooperative with their subsidiary Degesch, which had produced Zyklon B for the gassing of the Jews in AuschwitzBirkenau, Lemkin believed that the defendants could be charged using the concept of genocide. ${ }^{121}$

In the Medical trial, the prosecution followed Lemkin's suggestion and described human experiments, sterilization, castrations, and "euthanasia" in sanatoriums and concentration camps as "techniques of genocide." ${ }^{122}$ In addition, the prosecutors established a close connection to the Nazi extermination policy in the occupied territories: "The thanatological knowledge [the science of producing death], derived in part from these [human] experiments, supplied the techniques for genocide, a policy of the Third Reich, exemplified in the 'euthanasia' program in the widespread slaughter of Jews, Gypsies, Poles, and Russians." ${ }^{123}$ Deputy Chief Counsel James M. McHaney repeatedly emphasized the heterogeneity of the victims of medical crimes. ${ }^{124}$ In their verdict, the judges followed the prosecution to the extent that they regarded human experiments and sterilization as an integral part of Nazi policy—although they did not call this policy 'genocide.'125

In the RuSHA trial, high-ranking employees of four selected SS offices, all of whom had worked under the institutional umbrella of the Reich Commissioner for the Strengthening of Germandom (Reichskommissar für die Festigung deutschen Volkstums, RKFDV), were accused. The charges comprised deportations, forced Germanization, forced recruitment, forced abortions, the abduction of children, the prevention of marriages, executions as a result of racially prohibited sexual intercourse, looting, and participation in the persecution and extermination of the Jews. ${ }^{126}$ The prosecution assumed that the fourteen accused had played leading roles in the implementation of the comprehensive and "coordinated plan" of destroying the "national groups" in the territories occupied by Germany. The prosecutors explicitly relied on Lemkin's original concept:

These techniques of genocide, while neither so quick nor perhaps so simple as outright mass extermination, are by the very nature of things far more cruel and equally effective. If crimes such as these are allowed to go unpunished, the future of humanity is in far more danger than if an occasional murderer goes free. It is the enormity and far-reaching effects of these crimes that give this case its significance. ${ }^{127}$

In his closing statement, the main prosecutor-again McHaney-said that the Nazi policy of strengthening Germandom (or Volkstum policy) had been a program of "genocide," composed of two intertwined elements:

Genocide, as practiced by the Nazis, was a two-edged sword, both aspects of which were equally criminal. The positive side, according to the German concept, was the Germanization program by which they sought to strengthen themselves by adding to their population large

\footnotetext{
${ }^{121}$ Weindling, Victims, Witnesses, 78; Jonathan A. Bush, "The Prehistory of Corporations and Conspiracy in International Criminal Law: What Nuremberg Really Said," Columbia Law Review 109 (2009), 1179-1180. (Lemkin's Memorandum of 13 Jan 1946 is included in the appendix).

${ }^{122}$ Raphaël Lemkin, "Genocide as a Crime under International Law," The American Journal of International Law 41 (1947), 147, fn. 6; Michael R. Marrus, "The Doctor's Trial in Historical Context," Bulletin of the History of Medicine 73 (1999), 116; Paul Weindling, Nazi Medicine and the Nuremberg Trials: From Medical War Crimes to Informed Consent (Basingstoke: Palgrave Macmillan, 2004), 170, 179-187, 225-232.

${ }^{123}$ Medical Case, Opening Statement of the prosecution, 9 Dec 1946, TWC, I, 38.

${ }^{124}$ Ibid., 48.

${ }^{125}$ Medical Case, Opinion and Judgment, 19 Aug 1947, TWC, II, 181, 183, 197, 278.

${ }^{126}$ RuSHA Case, Indictment, 1 July 1947, TWC, IV, 608-618. See also Isabel Heinemann, 'Rasse, Siedlung, deutsches Blut.' Das Rasse- und Siedlungshauptamt der SS und die rassenpolitische Neuordnung Europas (Göttingen: Wallstein, 2003), 565-580; Alexa Stiller, "Die Volkstumspolitik der SS vor Gericht: Strategien der Anklage und Verteidigung im Nürnberger RuSHA-Prozess, 1947-1948," in Leipzig - Nürnberg - Den Haag: Neue Fragestellungen und Forschungen zum Verhältnis von Menschenrechtsverbrechen, justitielle Säuberung und Völkerstrafrecht, ed. Ministry of Justice Nordrhein-Westfalen (Düsseldorf, 2008), 66-86.

${ }^{127}$ McHaney referred to the Einsatzgruppen trial. See RuSHA Case, Opening Statement of the Prosecution, 20 Oct 1947, TWC, IV, 626-627.
} 
groups of people selected from among the populations of the conquered territories, and by forcing the German language, culture, citizenship, and ideals upon those so selected. The negative side of this program, through which the so-called positive side was in equal measure accomplished, was the deliberate extermination and enslavement of the remaining population of these conquered territories. Thus, Germany would be strengthened by adding to its population, and its neighbors would be weakened by subtracting from their population, and the strength of Germany would thereby be proportionately increased. ${ }^{128}$

Again, the judges approved of the claim that the accused had produced a "Germanization program," but did not call it genocide. ${ }^{129}$ With regard to the persecution and extermination of Jews, they concluded that crimes against the Jewish population were comparable to crimes against the Polish population. ${ }^{130}$ Ironically, Lemkin had no relation to Case 8, which deployed the original genocide most elaborately of all Nuremberg trials. Lemkin ultimately did not learn how it had come that his original concept was used in the RuSHA trial until February 1949 when he discovered that it had been Léon Poliakov who had proposed it to the American prosecutors for conducting this trial. ${ }^{131}$

The Einsatzgruppen trial took place at the same time as the RuSHA trial. Here, the prosecution also accused the defendants of a "plan of genocide": "they [the Einsatzgruppen] were to destroy all those denominated Jew, political official, gypsy, and those other thousands called 'asocial' by the self-styled Nazi superman." ${ }^{132}$ The Nazi motive for this "crime of genocide" had been racial ideology, but the Jews were not the only group to be destroyed, the prosecutors emphasized again and again. ${ }^{133}$ The judges stated in their judgment that the fundamental crime that had been tried in this case could simply be called murder. ${ }^{134}$ In other words, in their view, mass murder did not really require a separate element of an offense. At the same time, however, the judges pointed out that the Einsatzgruppen murders had been committed in a special way, calling them "ultramodern executions." 135 In their judgment, they called the extermination of the Jews a "genocide program" and meant more than just the technique. ${ }^{136}$

While the judgments in the RuSHA and Einsatzgruppen trials did not completely incorporate the concept of genocide, judge Michael Musmanno, who was involved in the Milch, the Pohl, and the Einsatzgruppen trials, finally decided to use Lemkin's term in his concurring opinion in the Pohl trial (the third SS case focusing the Economic and Administrative Main Office which was in charge of the concentration camps). He wrote: "[T]he trend of modernity toward mechanization and assembly line methods was not overlooked even in this most modern of achievementsgenocide-abusiveness so novel that a new name had to be coined for it. Genocide [is] the scientific extermination of a race." 137 Paraphrasing Lemkin, 'genocide' in Musmanno's conceptualization stood for industrial mass killings.

The RuSHA's failure to endorse the concept of genocide and the multiple, sporadic, and vague uses of genocide in connection with mass murder in the other SS trials, further changed the trajectory of the concept. All three sentences were passed after the UN resolution of 11 December 1946 on the concept of genocide. In contrast to the later Convention for the Prevention of Genocide

\footnotetext{
${ }^{128}$ RuSHA Case, Closing Statement of the Prosecution, 13 Feb 1948, TWC, V, 31.

${ }^{129}$ RuSHA Case, Opinion and judgment, 10 March 1948, TWC, V, 90.

${ }^{130}$ Ibid., 152.

${ }^{131}$ See Tanya Elder, "What You See Before Your Eyes: Documenting Raphaël Lemkin's Life by Exploring His Archival Papers, 1900-1959," Journal of Genocide Research 7, no. 4 (2005), 479; Priemel, Betrayal, 297.

${ }^{132}$ Einsatzgruppen Case, Opening Statement of the Prosecution, 29 Sept 1947, TWC, IV, 30-31. On the Einsatzgruppen trial see Hilary Earl, The Nuremberg SS-Einsatzgruppen Trial, 1945-1958. Atrocity, Law, and History (New York: Cambridge University Press, 2009).

${ }^{133}$ Einsatzgruppen Case, Opening Statement of the Prosecution, 29 Sept 1947, TWC, IV, 32-33.

${ }^{134}$ Einsatzgruppen Case, Opinion and Judgment, 8-9 April 1948, TWC, IV, 411.

${ }^{135}$ Ibid., 450.

${ }^{136}$ Ibid., 469-470.

${ }^{137}$ Pohl Case, Concurring Opinion by Judge Musmanno, 3 Nov 1947, TWC, V, 1135. See also Earl, Prosecuting Genocide, 333.
} 
of December 1948, the 1946 resolution was not clearly limited to mass murder and still contained the cultural extermination of groups. At the same time, however, the aspect of forced resettlement and forced assimilation-unlike Lemkin's original concept-had already disappeared. ${ }^{138}$ The UN resolution declared, "genocide is a denial of the right of existence of entire human groups, as homicide is the denial of the right to live of individual human beings." The resolution also stated: "such denial of the right of existence... results in great losses to humanity in the form of cultural and other contributions represented by these human groups..." ${ }^{139}$ It was Lemkin who had written the first version of this resolution. ${ }^{140}$

Following the SS proceedings within the NMT trial series, the role of the SS (including the SD) in the persecution and extermination of the Jews had finally been established. As Jan Erik Schulte emphasized, the SS had thus become the "alibi" of West German society. ${ }^{141}$ The interpretation that one organization within the Nazi regime was primarily responsible for all violent crimes should have far-reaching consequences in the early Federal Republic of Germany. Although the administration was cleaned up of former SS members, other members of the Nazi party and highranking officials in the former Nazi ministries were able to continue working unhindered in the public service of the young democracy. ${ }^{142}$ Apart from these consequences for West German society, however, the American prosecution had also recognized in 1947 on the basis of the Einsatzgruppen trial that conducting "atrocity cases," i.e. cases that focused on violent crimes and direct offenders, resulted in a more straightforward determination of the defendants' guilt and thus promised quick, cost-effective proceedings. After all, on the basis of international criminal law, it was easier to prove individual guilt in mass murders than participation in a criminal state policy. ${ }^{143}$

The Ministries trial, which began on November 1, 1947 and lasted until April 14, 1949, reflected this interpretation. In these proceeding, the non-SS defendants were only accused of complicity and connivance in the murder of the Jews. (The same applied to the High Command trial. The outcome there was that the Wehrmacht came out with 'clean hands' from the Nuremberg trials. ${ }^{144}$ ) The Ministries trial changed from a trial primarily focused on the high-ranking personnel of the Foreign Office into a trial focusing on the two former full-time SS employees among the defendants, Walter Schellenberg and Gottlob Berger. The latter received a sentence of 25 years imprisonment the most severe sentence delivered in this case. ${ }^{145}$ Although the prosecutors at the beginning of the trial, as in previous proceedings, still interpreted the term genocide in such a way that it not only meant the murder of one group, but also of different groups, different techniques, or even complementary Germanization, ${ }^{146}$ this broad term was completely lost in the course of the trial. In its closing statement, the prosecution authority only used the term genocide once-but defined it exclusively as mass murder of the Jews. ${ }^{147}$

Consequently, the judges no longer used the concept of genocide in their judgment in Case 11 either, although some of the defendants were explicitly found guilty of Germanization and

\footnotetext{
${ }^{138}$ Stiller, Semantics of Extermination.

${ }^{139}$ United Nations, Resolution 96 (I), The Crime of Genocide, December 11, 1946, accessed October 9, 2018, http://www. un.org/documents/ga/res/1/ares1.htm.

${ }^{140}$ Lemkin, Genocide, 148-150. See also Schabas, Genocide; Cooper, Raphaël Lemkin.

${ }^{141}$ Schulte, The SS.

${ }^{142}$ The literature is numerous and due to the current research on ministries in the early Federal Republic of Germany, a comprehensive assessment of the extent of the old Nazis' network is taking place. See e.g. Norbert Frei, Adenauer's Germany and the Nazi Past: The Politics of Amnesty and Integration (New York: Columbia University Press, 2002).

${ }^{143}$ Douglas, From IMT to NMT.

${ }^{144}$ High Command Case, Judgment, 27-28 Oct 1948, TWC, XI, 462-697. See also Stiller, Semantics of Extermination. On the High Command trial in general see Valerie Hébert, Hitler's Generals on Trial. The Last War Crimes Tribunal at Nuremberg (Lawrence: University Press of Kansas, 2010).

${ }^{145}$ Dirk Pöppmann, “Im Schatten Weizsäckers? Auswärtiges Amt und SS im Wilhelmstraßen-Prozess," in NMT. Die Nürnberger Militärtribunale zwischen Geschichte, Gerechtigkeit und Rechtschöpfung, eds. Kim C. Priemel and Alexa Stiller (Hamburg: Hamburger Edition, 2013), 320-352. Cf. Eckart Conze, et. al., eds., Das Amt und die Vergangenheit. Deutsche Diplomaten im Dritten Reich und in der Bundesrepublik (Munich: Blessing, 2010), 375-435.

${ }^{146}$ Ministries Case, Indictment, 4 Nov 1947, TWC, XII, 44.

${ }^{147}$ Ministries Case, Closing Statement of the Prosecution, 9 Nov 1948, TWC, XIV, 41.
} 
connected expulsion crimes. ${ }^{148}$ In contrast to the RuSHA trial, the judges did not see any linkage between forced population removals, forced assimilation procedures, and the murder of the Jews. The anti-Semitic policy was regarded by the judges as central for the dictator: "Hitler made the Jewish persecution one of the primary subjects of his policy to gain and retain power." ${ }^{149}$ The judges also simplified and personalized the implementation of the mass murder: "It was Goering who on 31 July 1941 ordered Himmler, as Reich Leader SS, and Heydrich as Chief of the RSHA [Reichssicherheitshauptamt, Reich Security Main Office], to plan and execute the Final Solution of the Jewish Question within the spheres of German influence in Europe." ${ }^{\prime 150}$ In conclusion, the mass murder of European Jews was no longer defined as a process based on the division of labor within the criminal state, but rather as a sole SS undertaking. Judge Powers even claimed in his dissenting verdict: "The evidence by those who were on the inside of this terrible extermination program strongly tends to show that not over 100 people in all were informed about the matter." 151 From today's perspective, one can only assume that Judge Powers was unable to cope with the scale of the mass crimes to be prosecuted and the perpetrators to be punished-or wanted to close the chapter quickly.

At this point it can be summarized that by 1949 a coherent interpretation of the persecution and extermination of the Jews had finally emerged, which was composed of the following partial aspects: First, the mass murder of the Jews was considered distinct from other crimes. Secondly, the organization of the SS (including the SD and the Gestapo), or rather only a small group of persons within it, were primarily responsible for these crimes. Thirdly, it was the intention and anti-Semitism of the leading Nazis, above all Hitler, which structured the extermination from an early stage. This interpretation was perfectly suited to the changing political conditions of the coming Cold War, the emergence of two German states, and the planned western alliance of West Germany. From 1947 onwards, these political factors generated pressure from both sides of the Atlantic to end the trials. There is no doubt that the political interests of the Cold War affected the judges. The efforts of the US lawyers around Taylor to work out the connections between economy, party, Wehrmacht, and ministries were a sophisticated approach for an international criminal procedure, but not successful in its implementation. The structures of the Nazi regime's policy of division of labor between persecution and extermination were lost in the NMT's institutional approach. The focus on the SS as the dominant perpetrator organization involuntarily helped to support exculpatory narratives of entrepreneurs, ministry officials, and the military.

\section{Conclusions}

The correlation of the concept of genocide and the Holocaust was, as shown, complex in the years 1945 to 1949. Above all, the relationship was marked by contradictions and ambiguities. As long as Axis Rule served as the basis for the definition of genocide, there was room for maneuver in applications of the concept. As laid out in Lemkin's book, the Nazi regime's entire policy of persecution and extermination could be described and interpreted as a means of stabilizing and expanding Nazi rule in Germany and the occupied territories, of conquering new "living space," and supporting Germany's economic and national supremacy. In this interpretation, the mass murder of European Jews was one of many Nazi techniques for achieving these objectives. This view was expressed in particular by the French, but also by the British and Soviet prosecutions at the IMT. But even at the first Nuremberg trial, there were also doubts about this view. Jackson was the first and most prominent of the prosecutors who understood the particular character of the extermination of European Jews as an unprecedented crime, but neither he nor the US prosecution

\footnotetext{
${ }^{148}$ Cf. Alexa Stiller, "Nürnberger Prozesse," in Lexikon der Vertreibungen. Deportation, Zwangsaussiedlung und ethnische Säuberung im Europa des 20. Jahrhunderts, ed. by Detlef Brandes, Holm Sundhaussen, and Stefan Troebst (Wien: Böhlau, 2010), 481-484.

${ }^{149}$ Ministries Case, Judgment, 11-13 Apr 1949, TWC, XIV, 470.

${ }^{150}$ Ibid., 865.

${ }^{151}$ Ministries Case, Dissenting Opinion of Judge Powers, 13 April 1949, TWC, XIV, 910. For that reason, Powers found von Weizsäcker, Woermann, Steengracht von Moyland, Veesenmayer, Dietrich, Schwerin von Krosigk and Puhl not guilty for taking part in the extermination of the Jews. See ibid., 909-931.
} 
persisted in this interpretation. Eventually, Jackson's positioning of the Holocaust within all Nazi crimes remained ambiguous.

The trial's pointed emphasis on the role of the persecution and extermination of the Jews as part of the charge of crimes against humanity led to a broad presentation of the complex of the Holocaust with all the various temporal and spatial developments, with the different murder methods of the Jewish population groups in Western, Eastern, and Southeastern Europe, and with the organized labor division of extermination. This picture of the destruction of Europe's Jewry presented in court was very comprehensive and almost complete. However, the lawyers did not clearly identify the motives behind these actions. Limiting the circle of indicted perpetrators proved to be a dead end. At the same time, by conflating the crimes against humanity with the Jewish Case, the IMT adopted the use of the genocide concept as an alternative interpretation of events-possibly in order to avoid emphasizing the Jewish Case too strongly.

Lauterpacht's idea to focus the IMT trial on the persecution and extermination of European Jews with the new statutory offense of crimes against humanity was apparently not enough to make the world aware of attacks against Jews as a group. Turning to a different concept, which explicitly emphasized groups and centered on mass murder was a logical consequence, probably not only for Lemkin. Whether this possibly explains Lemkin's own development from his initial broad concept of genocide to the pointed concept in the Genocide Convention, however, still has to be decisively clarified. Further studies on interpretations of the connection between the Holocaust and other forms of Nazi violence in the first years after the end of the war, especially from contemporary Jewish perspectives, are also necessary. In Harvest of Hate, from 1951, Poliakov saw the destruction of Europe's Jews as part of a larger Nazi project-even if he interpreted the Holocaust as unique:

The plans the Nazis entertained for the conquered peoples, or so-called 'inferior races,' were not so utterly unprecedented as their attempt to exterminate out of hand the entire Jewish people; ... Nevertheless, though this kind of persecution [of the 'inferior peoples'] had a more rational point of departure and resorted to more subtle techniques, in the final analysis it led to the same goal: the physical suppression of other peoples. The same word 'genocide' applies to the persecution of the 'inferior peoples,' even if this was sometimes a 'delayed' genocide... As soon as one surveys the whole ensemble of Nazi racial policy and practice, one perceives the true significance of the extermination of the Jews: as a warning sign of greater and more general holocausts to come. ${ }^{152}$

Especially the RuSHA case in the NMT trials, which had closely followed Lemkin's original genocide concept, was unable to convince either the judges, the world public, or the later historiography, not even Lemkin himself of the importance of this broader concept. Lemkin turned away from Nuremberg after the judgment of the IMT. The United Nations resolution on the "Crime of Genocide," in the preparation of which he played a major role, already went in a different direction with the elimination of expulsions as part of the genocide. The Nuremberg trials also took a different trajectory shortly thereafter. With the conviction of the SS, the SD, and the Gestapo as criminal organizations in the IMT trial, the focus on Eichmann and the "institutional approach" of Taylor's prosecution, the narrative that these organizations were solely responsible for the persecution and extermination of European Jews was fully established in the NMT trials. ${ }^{153}$

Parallel to the last two trials before the NMT, in which the Wehrmacht, the Foreign Office, and the other ministries were assigned only subordinate roles in the extermination of the European Jews, the process of unifying the concept of genocide at the UN also reduced the complexity of the original one. These two developments went hand in hand: on the one hand, the separation of the Holocaust from the rest of the Nazi policy of extermination, carried out by a supposedly monolithic group of the SS, took place in the course of international criminal law practice; on the

\footnotetext{
152 Poliakov, Harvest of Hate, 263-264.

${ }^{153}$ Hannah Arendt also placed the SS at the center of the extermination policy, in contrast to Raul Hilberg a few years later, who followed Neumann's and Poliakov's approach of an administrative division of labor. Cf. Hannah Arendt The Origins of Totalitarism (New York: Harcort, Brace, 1951); Hilberg, Destruction.
} 
other, the final legal definition of genocide, as an intended mass murder of a distinct national, ethnical, or religious group, was adopted by the UN. These developments made genocide, rather than crimes against humanity, synonymous with the Holocaust.

Why Lemkin approved of the reduction of his original concept will probably never be fully clarified. Whether it was a response to the fate of his family in the Nazi mass murder, whether he only became aware of the dimension of the Holocaust after the war, whether he wanted to emphasize the special character of the destruction of the European Jews, or whether there were other reasons, remains uncertain. Nonetheless, one thing is certain: Lemkin did recognize the possibility of political instrumentalization of the Genocide Convention and resisted its widespread application. In 1951, he rejected the petition We Charge Genocide: The Crime of the Government against the Negro People to the UN. The US government had not and would not commit 'genocide' against the African American population, he declared. That is, racist legislation and the social practice of lynching had nothing to do with his concept of 'genocide' in Lemkin's view. Worse still, he accused the authors of the petition of communist and "un-American" motives. ${ }^{154}$

One does not have to agree with the verdict of some OCCPAC or OCCWC staff members who more or less called Lemkin "crazy."155 But Lemkin's refusal to endorse the black activists in the USA weighs heavily in today's assessment of the "man on a mission." 156 After all, it is questionable for whom he was actually on this mission of creating the genocide offense. Ultimately, the 1948 Convention was so gutted by all the crucial prior circumstances of mass violence, particularly discrimination and the expulsion of determined groups, that it is hardly a political instrument for the persecuted and those condemned to extermination. Even genocide scholars and lawyers find it difficult to declare mass violent crimes as genocide. Historians also do themselves no favors when they use the term, which is legally standardized today, because it rarely (if at all) fits with the empirical findings and is usually an interpretative reduction of historical processes. ${ }^{157}$

As far as the Nuremberg trials are concerned, the use of the genocide concept relates to Lemkin, because he designed the concept. Genocide was a strong term at a time when there was no other concept for the Nazi policy of violence and extermination. The breadth of the concept also left plenty of room for interpretation, which the Nuremberg lawyers were quite pleased to embrace. However, Lemkin himself had little influence on the design and application of his concept in the Nuremberg trials. Behind the scenes in Nuremberg, Lauterpacht, Sheldon Glueck, and other international lawyers were much more important than Lemkin. ${ }^{158}$ With Neumann, Kirchheimer, Marcuse, and others, the US prosecutors had constitutional lawyers and political scientists at their side who had analyzed Nazi rule more precisely than Lemkin had done in Axis Rule. With Poliakov, Friedman, Wulf, and others, Jewish activists and historians participated in the processes, drawing both on their own experiences of persecution and extermination in their studies and on the testimonies of other survivors collected by them. Lemkin did not belong to any of these epistemic communities. He was a lone wolf with a mission, which was to write his concept of genocide into international criminal law and perhaps even himself into the annals of world history. In that respect, he succeeded impressively. In the end, the outcome of the correlation of Lemkin, his concept of genocide, and its interdependence to the Holocaust, with all the interpretative changes between 1944 and 1951, is a good example of contingency in historical processes.

\footnotetext{
${ }^{154}$ Carol Anderson, Eyes off the Prize: The United Nations and the African American Struggle for Human Rights, 1944-1955 (Cambridge, UK: Cambridge University Press, 2003), 181-201; Elder, What You See; Joe Docker, "Raphaël Lemkin, Creator of the Concept of Genocide: A World History Perspective," Humanities Research 16, no. 2 (2010), 59-66; Stephen Leonard Jacobs, "'We Charge Genocide': A Historical Petition all but Forgotten and Unkown," in Understanding Atrocities: Remembering, Representing, and Teaching Genocide, ed. Scott W. Murray (Calgary: University of Calgary Press, 2017), 125-143; Benjamin Meiches, "Genocide a Political Genealogy," (PhD diss., Johns Hopkins University, 2015), 100-105; Anton Weiss-Wendt, A Rhetorical Crime: Genocide in the Geopolitical Discourse of the Cold War (New Brunswick: Rutgers University Press, 2018).

${ }^{155}$ Ferencz cited from Earl, Prosecuting Genocide, 323; see fn. 29.

${ }^{156}$ Earl, Prosecuting Genocide, 317.

${ }^{157}$ Cf. Gerlach, The Extermination; Alexa Stiller, Völkische Politik: Praktiken der Exklusion und Inklusion in polnischen, französischen und slowenischen Annexionsgebieten, 1939-1945 (Göttingen: Wallstein, forthcoming).

${ }^{158}$ See Bush, The Supreme... Crime.
} 


\section{Bibliography}

Alberti, Michael. Die Verfolgung und Vernichtung der Juden im Reichsgau Wartheland, 1939-1945. Wiesbaden: Harrassowitz, 2006.

Anderson, Carol. Eyes off the Prize: The United Nations and the African American Struggle for Human Rights, 1944-1955. Cambridge, UK: Cambridge University Press, 2003.

Antipow, Lilia. "'Die wahrhaft räuberischen Pläne der hitlerischen Angreifer gegen die Sowjetunion.' Zur Eröffnungsrede des sowjetischen Hauptanklägers Roman Rudenko." In Das Internationale Militärtribunal von Nürnberg 1945/46. Die Reden der Hauptankläger neu gelesen und kommentiert, edited by Nürnberger Menschenrechtszentrum, 227-277. Hamburg: CEP Europäische Verlagsanstalt, 2015.

Arendt, Hannah. The Origins of Totalitarism. New York: Harcort, Brace, 1951.

Barrett, John Q. "Raphaël Lemkin and 'Genocide' at Nuremberg, 1945-1946." In The Genocide Convention Sixty Years after its Adoption, edited by Christoph Safferling and Eckart Conze, 35-54. The Hague: Asser Press, 2010.

Beer, Frank, Wolfgang Benz, and Barbara Distel, eds., Nach dem Untergang. Die ersten Zeugnisse der Shoah in Polen 1944-1947. Berichte der Zentralen Jüdischen Historischen Kommission. Berlin: Metropol, 2014.

Bloxham, Donald. Genocide on Trial. War Crimes Trials and the Formation of Holocaust History and Memory. Oxford: Oxford University Press, 2001.

Böhm, Otto and Rainer Huhle. "'Die wahre Klägerin vor den Schranken dieses Gerichts ist die Zivilisation.' Zur Eröffnungsrede des amerikanischen Hauptanklägers Robert H. Jackson." In Das Internationale Militärtribunal von Nürnberg 1945/46. Die Reden der Hauptankläger neu gelesen und kommentiert, edited by Nürnberger Menschenrechtszentrum, 21-59. Hamburg: CEP Europäische Verlagsanstalt, 2015.

Böttcher, Kurt, Karl Heinz Berger, Kurt Krolop, Christa Zimmermann, et. al., eds., Geflügelte Worte: Zitate, Sentenzen und Begriffe in ihrem geschichtlichen Zusammenhang. Leipzig: VEB Bibliographisches Institut, 1981.

Brudzyńska-Němec, Gabriela. "Polenbegeisterung in Deutschland nach 1830." In Europäische Geschichte Online, edited by the Institut für Europäische Geschichte. Mainz, 2010. Accessed October 9, 2018. http://www.ieg-ego.eu/brudzynskanemecg- 2010-de.

Bush, Jonathan. "'The Supreme... Crime' and Its Origins: The Lost Legislative History of the Crime of Aggressive War." Columbia Law Review 120 (2002), 2324-2424. https://doi.org/10.2307/1123729

--------. "The Prehistory of Corporations and Conspiracy in International Criminal Law: What Nuremberg Really Said." Columbia Law Review 109 (2009), 1094-1262.

Cesarani, David. "Challenging the 'Myth of Silence': Postwar Responses to the Destruction of Eurpean Jewry." In After the Holocaust: Challenging the Myth of Silence, edited by David Cesarani and Eric J. Sundquist, 15-38. London: Routledge, 2012. https://doi.org/10.4324/9780203803141

Claussen, Detlev. "Veränderte Vergangenheit. Über das Verschwinden von Auschwitz." In Shoah. Formen der Erinnerung. Geschichte, Philosophie, Literatur, Kunst, edited by Nicolas Berg, Jess Jochimsen, and Bernd Stiegler, 77-92. Munich: Fink, 1996.

Cooper, John. Raphaël Lemkin and the Struggle for the Genocide Convention. Basingstoke: Palgrave Macmillan, 2008.

Conze, Eckart, et. al., eds., Das Amt und die Vergangenheit. Deutsche Diplomaten im Dritten Reich und in der Bundesrepublik. Munich: Blessing, 2010.

Docker, Joe. "Raphaël Lemkin, Creator of the Concept of Genocide: A World History Perspective." Humanities Research 16, no. 2 (2010), 49-74. https://doi.org/10.22459/hr.xvi.02.2010.03

Douglas, Lawrence. "From IMT to NMT. The Emergence of a Jurisprudence of Atrocity." In Reassessing the Nuremberg Military Tribunals. Transitional Justice, Trial Narratives, and Historiography, edited by Kim C. Priemel and Alexa Stiller, 276-295. New York: Berghahn 2012. 
Dülffer, Jost. "The United Nations and the Origins of the Genocide Convention 1946-1948." In The Genocide Convention Sixty Years after its Adoption, edited by Christoph Safferling and Eckart Conze, 55-68. The Hague: Asser Press, 2010.

Earl, Hilary. The Nuremberg SS-Einsatzgruppen Trial, 1945-1958. Atrocity, Law, and History. New York: Cambridge University Press, 2009.

--------. "Prosecuting Genocide before the Genocide Convention: Raphaël Lemkin and the Nuremberg Trials, 1945-1949." Journal of Genocide Research 15, no. 3 (2013), 317-337. https://doi.org/10.1080/14623528.2013.821225

Ehrenburg, Ilya and Vasily Grossman, eds. The Black Book: The Ruthless Murder of Jews by GermanFascist Invaders Throughout the Temporarily-Occupied Regions of the Soviet Union and in the Death Camps of Poland During the War of 1941-1945. New York: Holocaust Library, 1981.

Elder, Tanya. “What You See Before Your Eyes: Documenting Raphaël Lemkin's Life by Exploring His Archival Papers, 1900-1959." Journal of Genocide Research 7, no. 4 (2005), 469-499. https://doi.org/10.1080/14623520500349910

Fink, Carole. Defending the Rights of Others: The Great Powers, the Jews, and International Minority Protection, 1878-1938. Cambridge, UK: Cambridge University Press, 2004.

Frei, Norbert. Adenauer's Germany and the Nazi Past: The Politics of Amnesty and Integration. New York: Columbia University Press, 2002. https://doi.org/10.7312/frei11882

Friedlander, Henry. The Origins of Nazi Genocide: From Euthanasia to the Final Solution. Chapel Hill: University of North Carolina Press, 1995.

Gerlach, Christian. "Extremely Violent Societies: An Alternative to the Concept of Genocide." Journal of Genocide Research 8 (2006), 455-471. https://doi.org/10.1080/14623520601056299

--------. Extremely Violent Societies: Mass Violence in the Twentieth-Century World. Cambridge, UK: Cambridge University Press, 2010.

--------. The Extermination of the European Jews. Cambridge, UK: Cambridge University Press, 2016.

Hébert, Valerie. Hitler's Generals on Trial. The Last War Crimes Tribunal at Nuremberg. Lawrence, KS: University Press of Kansas, 2010.

Heinemann, Isabel. 'Rasse, Siedlung, deutsches Blut.' Das Rasse- und Siedlungshauptamt der SS und die rassenpolitische Neuordnung Europas. Göttingen: Wallstein, 2003.

Heller, Kevin Jon. The Nuremberg Military Tribunals and the Origins of International Criminal Law. Oxford: Oxford University Press, 2011.

Hilberg, Raul. The Destruction of the European Jews. New York: Harper \& Row, 1961.

Hirsch, Francine. "The Soviets at Nuremberg: International Law, Propaganda, and the Making of the Postwar Order." American Historical Review 113, no. 3 (2008), 701-730. https://doi.org/10.1086/ahr.113.3.701

--------. "The Soviet Union, the Nuremberg Trials, and the Politics of the Postwar Moment." In Political Trials in Theory and History, edited by Jens Meierhenrich and Devin O. Pendas, 157183. Cambridge, UK: Cambridge University Press, 2016. https://doi.org/10.1017/9781139941631.006

Irvin-Erickson, Douglas. Raphä̈l Lemkin and the Concept of Genocide. Philadelphia: University of Pennsylvania Press, 2017. https://doi.org/10.1007/s12142-017-0475-1

Jacobs, Stephen Leonard. "We Charge Genocide': A Historical Petition all but Forgotten and Unkown." In Understanding Atrocities: Remembering, Representing, and Teaching Genocide, edited by Scott W. Murray, 125-143. Calgary: University of Calgary Press, 2017. https://doi.org/10.2307/j.ctv6gqvg8.11

Jackson, Robert H. Report of Robert H. Jackson, United States Representative to the International Conference on Military Trials, London 1945. Washington, DC: 1949.

Jockusch, Laura. "Justice at Nuremberg? Jewish Responses to Nazi War-Crime Trials in AlliedOccupied Germany." Jewish Social Studies 19, no. 1 (2012), 107-147.

https://doi.org/10.2979/jewisocistud.19.1.107

-------. Collect and Record! Jewish Holocaust Documentation in Early Postwar Europe. New York: Oxford University Press, 2013. 
Kieser, Hans-Lukas. “Die Armenierverfolgungen in der spätosmanischen Türkei. Neue Quellen und Literatur zu einem unbewältigten Thema." Schweizerischen Zeitschrift für Geschichtel Revue Suisse d'histoire 51, no. 1 (2001), 97-105.

Kirchheimer, Otto. Political Justice. The Use of Legal Procedure for Political Ends. Princeton: Princeton University Press, 1961.

Koskenniemi, Martti. "Hersch Lauterpacht and the Development of International Criminal Law." Journal of International Criminal Justice 2, no. 3 (2004), 810-825. https://doi.org/10.1093/jicj/2.3.810

Kraft, Claudia. "Völkermord als delictum iuris gentium - Raphaël Lemkins Vorarbeiten für eine Genozidkonvention." Jahrbuch des Simon-Dubnow-Instituts 4 (2005), 79-98.

Kunz, Josef L. "The Future of the International Law for the Protection of National Minorities." The American Journal of International Law 39 (1945), 89-95.

--------. "The United Nations Convention on Genocide." The American Journal of International Law 43 (1949), 738-746.

Kurths, Anja. Shoahgedenken im israelischen Alltag: Der Umgang mit der Shoah in Israel seit 1948 am Beispiel der Gedenkstätten Beit Lohamei HaGetaot, Yad Vashem und Beit Terezin. Berlin: Frank \& Timme, 2008.

Leff, Lisa Moses. The Archive Thief: The Man Who Salvaged French Jewish History in the Wake of the Holocaust. New York: Oxford University Press, 2015.

Lemkin, Raphaël. Axis Rule in Occupied Europe. Laws of Occupation, Analysis of Government, Proposals for Redress. Washington, DC: Carnegie Endowment for International Peace, 1944.

--------. "Genocide as a Crime under International Law." The American Journal of International Law 41 (1947), 145-151.

Lippman, Matthew. "A Road Map to the 1948 Convention on the Prevention and Punishment of Genocide." Journal of Genocide Research 4 (2002), 177-195.

https://doi.org/10.1080/14623520220137958

Marcuse, Herbert. "Der Kampf gegen den Liberalismus in der totalitären Staatsaufassung." In Faschismus und Kapitalismus. Theorien über die sozialen Ursprünge und die Funktion des Faschismus, edited by Wolfgang Abendroth, 39-74. Frankfurt am Main: Europäische Verlagsanstalt, 1967.

Marrus, Michael R. "The Holocaust at Nuremberg." Yad Vashem Studies 26 (1998), 5-41.

--------. "The Doctor's Trial in Historical Context." Bulletin of the History of Medicine 73 (1999), 106123.

. "A Jewish Lobby at Nuremberg: Jacob Robinson and the Institute of Jewish Affairs, 194546." Cardozo Law Review 27 (2006), 1651-1665. https://doi.org/10.1515/9783110944846.63

Mazower, Mark. Dark Continent: Europe's Twentieth Century. London: Allen Lane, 1998.

Meiches, Benjamin. “Genocide a Political Genealogy.” PhD diss., Johns Hopkins University, 2015.

Meierhenrich, Jens and Devin O. Pendas, eds. Political Trials in Theory and History. Cambridge UK: Cambridge University Press, 2016.

Milton, Sybil. "The Context of the Holocaust." German Studies Review 13 (1990), 269-283.

Morsink, Johannes. "Cultural Genocide, the Universal Declaration, and Minority Rights." Human Rights Quarterly 21 (1999), 1009-1060. https://doi.org/10.1353/hrq.1999.0052

Moses, A. Dirk. "Lemkin, Culture, and the Concept of Genocide." In The Oxford Handbook of Genocide Studies, edited by Donald Bloxham and A. Dirk Moses, 19-41. Oxford: Oxford University Press, 2010.

Neumann, Franz L. Behemoth. The Structure and Practice of National Socialism, 1933-1944, 2nd ed. Toronto: Oxford University Press, 1944.

Perels, Joachim. “Fast vergessen: Franz L. Neumanns Beitrag zur Konzipierung der Nürnberger Prozesse. Eine Erinnerung aus Anlaß seines 100. Geburtstages." Kritische Justiz 34 (2001), 117-125.

Petrie,Jon. "TheSecularWord HOLOCAUST.Scholarly Myths,History, and 20th Century Meanings." Journal of Genocide Research 2, no. 1 (2000), 31-63. https://doi.org/10.1080/146235200112409

Poliakov, Léon. Harvest of Hate. The Nazi Program for the Destruction of the Jews of Europe, reprinted. New York: Holocaust Library, 1986. 
Pöppmann, Dirk. "Im Schatten Weizsäckers? Auswärtiges Amt und SS im WilhelmstraßenProzess." In NMT: Die Nürnberger Militärtribunale zwischen Geschichte, Gerechtigkeit und Rechtschöpfung, edited by Kim C. Priemel and Alexa Stiller, 320-352. Hamburg: Hamburger Edition, 2013.

Priemel, Kim C. and Alexa Stiller. "Nuremberg's Narratives. Revising the Legacy of the 'Subsequent Trials'." In Reassessing the Nuremberg Military Tribunals. Transitional Justice, Trial Narratives, and Historiography, edited by Kim C. Priemel and Alexa Stiller, 1-21. New York: Berghahn, 2012.

--------. The Betrayal: The Nuremberg Trials and the German Divergence. Oxford: Oxford University Press, 2016.

--------. “Wo ‘Nürnberg' liegt. Zur historischen Verortung der Nuernberg Military Tribunals." In NMT. Die Nürnberger Militärtribunale zwischen Geschichte, Gerechtigkeit und Rechtschöpfung, edited by Kim C. Priemel and Alexa Stiller, 9-63. Hamburg: Hamburger Edition, 2013.

Rabinbach, Anson. "The Challenge of the Unprecedented - Raphaël Lemkin and the Concept of Genocide." Simon Dubnow Institute Yearbook 4 (2005), 397-420.

Sands, Philippe. East West Street. On the Origins of Genocide and Crimes against Humanity. London: Weidenfeld \& Nicholson, 2016.

Schabas, William A. Genocide in International Law: The Crimes of Crime. Cambridge, UK: Cambridge University Press, 2000.

Scheffler, Wolfgang. Die Judenverfolgung im Dritten Reich: 1933-1945. Berlin: Colloquium Verlag, 1960.

Scheuermann, Martin. Minderheitenschutz contra Konfliktverhütung? Die Minderheitenpolitik des Völkerbundes in den zwanziger Jahren. Marburg: Verlag Herder-Institut, 2000.

Schulmeister-André, Irina. Internationale Strafgerichtsbarkeit unter sowjetischem Einfluss: Der Beitrag der UdSSR zum Nürnberger Hauptkriegsverbrecherprozess. Berlin: Duncker \& Humblot, 2016. https://doi.org/10.3790/978-3-428-54867-5

Schulte, Jan Erik. "The SS as the 'Alibi' of a Nation? Narrative Continuities from the Nuremberg Trials to the 1960s." In Reassessing the Nuremberg Military Tribunals. Transitional Justice, Trial Narratives, and Historiography, edited by Kim C. Priemel and Alexa Stiller, 134-160. New York: Berghahn 2012.

Schwan, Chrétien Frédéric. Nouveau Dictionnaire françois-allemand: Extrait de son grand Dictionnaire par lui même. Tome II, nouv. éd., rev., corr. et augm. Tübingen: Cotta, 1807.

Segesser, Daniel Marc and Myriam Gessler. "Raphaël Lemkin and the International Debate on the Punishment of War Crimes (1919-1948)." Journal of Genocide Research 7 (2005), 453-468. https://doi.org/10.1080/14623520500349902

Segesser, Daniel Marc. Recht statt Rache oder Rache durch Recht? Die Ahndung von Kriegsverbrechen in der internationalen fachwissenschaftlichen Debatte 1872-1945. Paderborn: Schöningh, 2010.

Sémelin, Jacques. Purify and Destroy: The Political Uses of Massacre and Genocide. London: Hurst, 2013.

Shandler, Jeffrey. While America Watches: Televising the Holocaust. Oxford: Oxford University Press, 1999.

Shklar, Judith N. Legalism: Law, Morals and Political Trials. Cambridge, MA: Harvard University Press, 1964.

Stiller, Alexa. "Die Volkstumspolitik der SS vor Gericht: Strategien der Anklage und Verteidigung im Nürnberger RuSHA-Prozess, 1947-1948." In Leipzig - Nürnberg - Den Haag: Neue Fragestellungen und Forschungen zum Verhältnis von Menschenrechtsverbrechen, justitielle Säuberung und Völkerstrafrecht, edited by the Ministry of Justice Nordrhein-Westfalen, 6686. Düsseldorf, 2008.

. "Nürnberger Prozesse." In Lexikon der Vertreibungen. Deportation, Zwangsaussiedlung und ethnische Säuberung im Europa des 20. Jahrhunderts, edited by Detlef Brandes, Holm Sundhaussen, and Stefan Troebst, 481-484. Wien: Böhlau, 2010.

--------. "Semantics of Extermination. The Use of the New Term of Genocide in the Nuremberg Trials and the Genesis of a Master Narrative." In Reassessing the Nuremberg Military 
Tribunals. Transitional Justice, Trial Narratives, and Historiography, edited by Kim C. Priemel and Alexa Stiller, 104-133. New York: Berghahn, 2012.

. "Die Nürnberger Prozesse und der Holocaust. Frühe Interpretationen zur Verfolgung und Vernichtung der europäischen Juden." Einsicht 14 (2015), 16-23.

"Historians Behind the Scenes: Léon Poliakov and the French Prosecution at the International Military Tribunal in Nuremberg." Presentation, Amsterdam, November 30, 2016. NIOD Institute for War, Holocaust, and Genocide Studies.

--------. Völkische Politik: Praktiken der Exklusion und Inklusion in polnischen, französischen und slowenischen Annexionsgebieten, 1939-1945. Göttingen: Wallstein, forthcoming.

Stone, Dan. "Raphaël Lemkin on the Holocaust." Journal of Genocide Research 7 (2005), 539-550. https://doi.org/10.1080/14623520500349985

Taylor, Telford. Anatomy of the Nuremberg Trials: A Personal Memoir. New York: Knopf, 1992.

Trial of the Major War Criminals before the International Military Tribunal, Volumes 1-42. November 14, 1945- October 1, 1946. Nuremberg: 1947-1949.

Trials of War Criminals before the Nuremberg Military Tribunals under Control Council Law No. 10, Volumes 1-15. October 1946 - April 1949. Washington, DC: 1950-1953.

United Nations. General Assembly Resolution 260, Convention on the Prevention and Punishment of the Crime of Genocide. December 9, 1948. UN Doc. A/RES/260(III).

-------. Resolution 96 (I), The Crime of Genocide. December 11, 1946. Accessed October 9, 2018. http:// www.un.org/documents/ga/res/1/ares1.htm.

Vrdoljak, Ana Filipa. "Human Rights and Genocide: The Work of Lauterpacht and Lemkin in Modern International Law." The European Journal of International Law 20, no. 4 (2010), 11631194. https://doi.org/10.1093/ejil/chp090

Weber, Claudia. Krieg der Täter: die Massenerschiessungen von Katyń. Hamburg: Hamburger Edition, 2015.

Weindling, Paul. Nazi Medicine and the Nuremberg Trials: From Medical War Crimes to Informed Consent. Basingstoke: Palgrave Macmillan, 2004.

Weindling, Paul. "Victims, Witnesses, and the Ethical Legacy of the Nuremberg Medical Trial." In Reassessing the Nuremberg Military Tribunals. Transitional Justice, Trial Narratives, and Historiography, edited by Kim C. Priemel and Alexa Stiller, 74-103. New York: Berghahn 2012.

Weinke, Annette. Die Nürnberger Prozesse. Munich: C.H. Beck, 2006.

Weiss-Wendt, Anton. A Rhetorical Crime: Genocide in the Geopolitical Discourse of the Cold War. New Brunswick, NJ: Rutgers University Press, 2018. https://doi.org/10.2307/j.ctt1t89jvc

-------. The Soviet Union and the Gutting of the UN Genocide Convention. Madison, WI: University of Wisconsin Press, 2017. 